\title{
Small molecule inhibitors against PD-1/ PD-L1 immune checkpoints and current methodologies for their development: a review
}

\author{
Chang Liu* ${ }^{*}$, Navindra P. Seeram and Hang Ma*
}

\begin{abstract}
Programmed death-1/programmed death ligand-1 (PD-1/PD-L1) based immunotherapy is a revolutionary cancer therapy with great clinical success. The majority of clinically used PD-1/PD-L1 inhibitors are monoclonal antibodies but their applications are limited due to their poor oral bioavailability and immune-related adverse effects (irAEs). In contrast, several small molecule inhibitors against PD-1/PD-L1 immune checkpoints show promising blockage effects on PD-1/PD-L1 interactions without irAEs. However, proper analytical methods and bioassays are required to effectively screen small molecule derived PD-1/PD-L1 inhibitors. Herein, we summarize the biophysical and biochemical assays currently employed for the measurements of binding capacities, molecular interactions, and blocking effects of small molecule inhibitors on PD-1/PD-L1. In addition, the discovery of natural products based PD-1/PD-L1 antagonists utilizing these screening assays are reviewed. Potential pitfalls for obtaining false leading compounds as PD-1/PD-L1 inhibitors by using certain binding bioassays are also discussed in this review.
\end{abstract}

Keywords: Cancer, Immunotherapy, PD-1/PD-L1, Natural products, Small molecules

\section{Introduction}

Tumors can bypass immune surveillance by exploiting immune-escape mechanisms including the induction of an immunosuppressive microenvironment and suppression of effector T cells' function in the tumor microenvironment $[1,2]$. Cancer immunotherapy is designed to re-activate anti-tumor immune response and enhance its effects, thereby restoring tumor immune suppression [3-5]. Activating $\mathrm{T}$ cell-mediated anti-tumor responses is one of the most effective strategies on the basis of the regulation of immune checkpoints, which are crucial receptors for preventing autoimmunity, protecting the host from tissue damage, and regulating self-tolerance [6-8].

\footnotetext{
*Correspondence: hichang813@uri.edu; hang_ma@uri.edu
} Bioactive Botanical Research Laboratory, Department of Biomedical and Pharmaceutical Sciences, College of Pharmacy, University of Rhode Island, Avedisian Hall Lab 440, 7 Greenhouse Road, Kingston, RI 02881, USA
$\mathrm{T}$ cell-mediated cancer immunotherapy is a breakthrough since its discovery $[9,10]$. The activation of cancer-specific $T$ cells eliminates cancer cells by the recognition of tumor-specific antigens [10,11]. T cell-mediated cancer immunotherapy consists of three steps. First, antigens are presented by antigen-presenting cells (APCs) such as dendritic cells (DCs) as antigenic peptides, which are recognized by the T-cell receptor (TCR; Signal 1) [12]. The secondary signal is then delivered when $\mathrm{B} 7$ proteins (CD80 and CD86) on the APCs engage with CD28 on the $\mathrm{T}$ cells, leading to the activation of $\mathrm{T}$ cells [13]. Subsequently, the activated cancer-specific $\mathrm{T}$ cells enter into the tumor sites and recognize tumor-specific antigens thereby destroying the cancer cells [13]. However, in the tumor microenvironment, cancer cells highly express coinhibitory protein ligands including CD80/86 and programmed death-ligand 1 (PD-L1) [14-16]. Co-inhibitory proteins including cytotoxic T-lymphocyte-associated protein 4 (CLTA-4) and programmed cell death protein 1 
(PD-1) are activated by binding to their ligands expressed on cancer cells [17-19]. Consequently, cancer-specific $\mathrm{T}$ cell activation is prevented so the cancer cells can escape from immune surveillance. Therefore, blockage of the co-inhibitory signals on the $\mathrm{T}$ cells and the activation of cancer-specific $\mathrm{T}$ cells represent a promising strategy in cancer immunotherapy.

PD-1 is a co-inhibitory receptor mainly expressed on the surface of $T$ cells [20]. PD-1's primary function is to suppress the $\mathrm{T}$ cells' activity by the regulation of the TCR signaling cascade [21-23]. High PD-L1 expression in tumor microenvironment is frequently observed in many types of cancers including Hodgkin's lymphoma, breast cancer, renal cell carcinoma, melanoma, lung cancer, gastric cancer, and hepatoma [24-30]. In the tumor microenvironment, PD-L1 binds to PD-1 leading to T cell dysfunction, whereas blockage of their interactions recovers the T cell's activity of destroying tumor cells [31, 32]. Previous studies reported that the blockage of the PD-L1/PD-1 interactions is a promising strategy for cancer immunotherapy $[18,32,33]$. Blockage of PD-L1/PD-1 interactions can terminate the PD-1 mediated-signaling pathways and reactivate the $\mathrm{T}$ cell-mediated anti-tumor responses by promoting $\mathrm{T}$ cell proliferation and enhancing effector $\mathrm{T}$ cell's function [32, 34]. Clinical studies reported that the blockade of PD-1/PD-L1 interactions can boost $\mathrm{T}$ cell-mediated antitumor responses, generate durable clinical responses, and prolong patient survival rate $[17,35]$. To date, monoclonal antibodies (mAbs) targeting PD-1 (e.g. Cemiplimab, Nivolumab, and Pembrolizumab) or PD-L1 (e.g. Durvalumab, Avelumab, and Atezolizumab) are approved by the United States FDA for the treatment of a series of malignancies [16, 36-38]. Although these mAbs exhibit promising therapeutic effectiveness in clinical studies, restrictions including immune-related adverse effects, immunogenicity, and high costs are imposed for the clinical utilization of antibody-based immune checkpoint inhibitors [15, 17, 39, 40]. In addition, these mAbs exert limited permeability in the tumor tissues due to their large size [41, 42]. Their relatively long half-life increases the difficulty in drug elimination, which may lead to severe side effects. Alternatively, small molecule inhibitors may possess favorable tumor penetration and oral bioavailability [42]. Moreover, small molecule inhibitors may exert other advantages such as fewer side effects, are easier self-administered, have shorter biological half-life, and are less expensive than mAbs, which have attracted great attention in pharmaceutical industries. However, most small molecule inhibitors against PD-1/PD-L1 are still in the early drug development stage with a focus on preclinical studies.

Currently, preclinical studies have demonstrated that small molecule inhibitors can exhibit superior capacities to inhibit tumor growth with favorable biosafety as compared to mAbs [42]. Among these small molecule inhibitors, several synthetic small molecules from Bristol Myers Squibb (e.g. BMS1166 and BMS202) and Curis Inc. (i.e. CA-170) exhibit promising tumor suppression effects in interrupting the PD-1/PD-L1 interactions [43, 44]. However, there are relatively fewer reports and preclinical studies on natural product-derived small molecule inhibitors.

Bioassays are crucial to assess the blockage effects of small molecules against the PD-1/PD-L1 interactions as well as their binding affinities and how their biological functions impact PD-1/PD-L1. Currently, bioassays to determine the potency of small molecule inhibitors against PD-1/PD-L1 include biophysical and biochemical assays, in vitro cell-based assays, and in vivo tumor xenograft model [45-47]. Biophysical and biochemical assays are used for the assessment of small molecule binding profiles and for the screening of potential inhibitors. In vitro cell-based assays and in vivo tumor xenograft models can evaluate small molecules' functional effects on PD-1/PD-L1. In addition, due to the encouraging promise of small molecule inhibitors against PD-1/ PD-L1, researchers have developed various robust and effective assays for screening PD-1/PD-L1 inhibitors.

Herein, PD-1/PD-L1 immune checkpoints and their interactions are summarized. In addition, natural product-based small molecule inhibitors against PD-1/PD-L1 and current methodologies employed for their development are reviewed. The potential pitfalls and future of small molecule inhibitors against PD-1/PD-L1 are also examined.

\section{PD-1/PD-L1 and their interactions}

PD-1 (CD279) is a transmembrane protein consisting of 288 amino acids belonging to the CD28 superfamily [28]. The structure of PD-1 consists of an extracellular $\mathrm{IgV}$ domain connected to a transmembrane region and an intracellular tail, which contains two phosphorylation sites on two motifs including the immunoreceptor tyrosine-based switch motif (ITSM) and immunoreceptor tyrosine-based inhibitory motif (ITIM) [28]. Immunoglobulin (Ig)-like extracellular domain is responsible for engagement and signaling transduction to intracellular domain. After engagement with PD-L1 (CD274; B7-H1) and PD-L2 (CD273; B7-DC), PD-1 delivers 'negative' signals to $\mathrm{T}$ cells to suppress $\mathrm{T}$ cell's activity. In addition, PD-1 is expressed on the surface of regulatory $\mathrm{T}$ cells, activated B cells, monocytes, macrophages, DCs, and natural killer cells [48]. However, the mechanisms of the regulation of PD-1 signaling pathways on these cells are unclear. 
PD-1 expression is dynamically changed and intricately regulated by host immune responses $[49,50]$. Usually, it is expressed at a low, basal level in resting naive $\mathrm{T}$ cells (Th0 cells) to maintain immunological tolerance. However, PD-1 is upregulated by a series of immune cells including CD4 and CD8 T cells, B cells, macrophages, and DCs in response to initial immune stimuli [51]. PD-1 is often down-regulated when the antigen is eliminated but its down-regulation can be observed prior to antigen clearance in the case of acute antigen exposure. By contrast, PD-1 expression maintains a high level in chronically stimulated antigen-specific $\mathrm{T}$ cells, which leads to their functional exhaustion in response to stimuli [52].

Similar to other B7 proteins, PD-L1 and PD-L2 are transmembrane glycoproteins [53]. Compared to PD-L2, PD-L1 is expressed on a variety of normal and immune cells including macrophages and DCs as well as cancer cells after exposure to pro-inflammatory stimuli [31]. In addition, PD-L2 is inducibly expressed in hematopoietic cells including macrophages, DCs, mast cells, and certain $B$ cell populations $[54,55]$. In the tumor microenvironment, PD-L1 expressed by cancer cells binds to its receptor PD-1 located on activated T cells on the tumor sites. This interaction consequently triggers inhibitory signals to the $\mathrm{T}$ cells and prevents the host immune system from suppressing the growth of tumor [56].

The structure of PD-L1 includes an extracellular domain followed by a transmembrane domain and an intracytoplasmic region [53]. As shown in Fig. 1b, the extracellular domain of PD-L1 consists of Ig variable distal and constant proximal regions. It is anchored to the membrane by a hydrophobic transmembrane sequence. The intracytoplasmic region consists of three conserved sequences including RMLDVEKC and DTSSK motifs, which are RNA pol-like motifs [57], and a QFEET motif. The DTSSK motif is a negative regulator of the RMLDVEKC motif, which is responsible for suppressing the phosphorylation of signal transducer and activator of transcription 3 in tumor cells [57].

The underlying mechanisms of the PD-1 signaling pathway are briefly summarized in Fig. 1a as PD-1 binds to PD-L1 suppressing ZAP70 and PI3K phosphorylation by recruiting Src homology 2 domain-containing protein tyrosine phosphatase (SHP)1 and SHP2 phosphatases to the ITSM and ITIM motifs in the intracellular tail [58]. Consequently, the TCR signaling cascade is terminated [59]. SHP1 can bind to the ITIM and ITSM motifs, whereas SHP2 preferentially binds to the ITSM $[60,61]$. However, it is still unknown whether SHP1 and SHP2 compete to bind to the ITSM or both bind to the intracellular tail. The engagement of PD-L1 with PD-1 leads to phosphorylation of ITSM and SHP-2 recruitment. As a result, the phosphatidylinositol 3-kinase (PI3K)/ Akt signaling pathway is suppressed [62, 63]. PI3K/Akt signaling pathway blockage further regulates a series of downstream cellular events including the activation of a

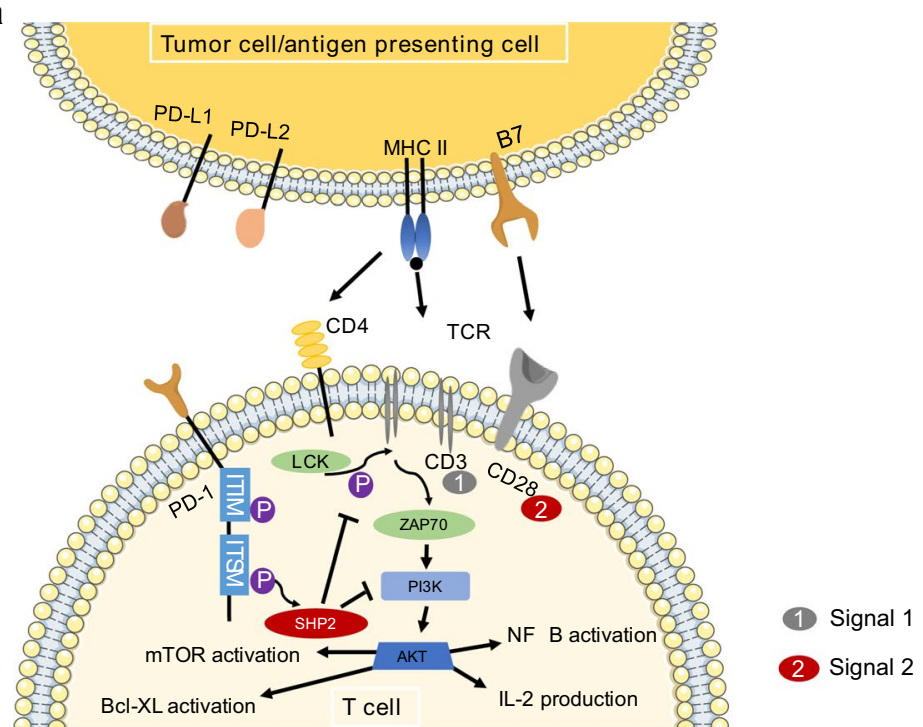

b

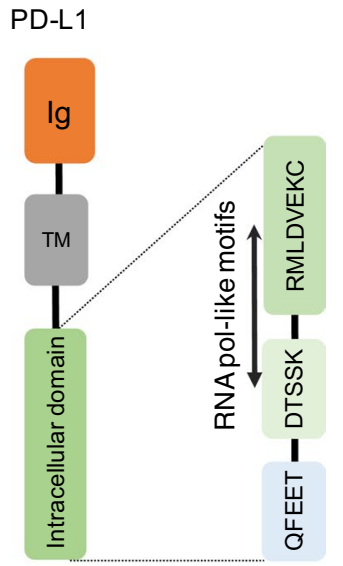

Fig. 1 The signaling pathway of PD-1/PD-L1. a PD-L1 consists of an extracellular domain, a transmembrane domain, and an intracytoplasmic region but lacks intracellular signaling. The intracytoplasmic region consists of three conserved sequences including RMLDVEKC, DTSSK, and QFEET motifs. The part of the RMLDVEKC motif and the entire DTSSK motif that have been identified by MotifFinder are RNA pol-like motifs. b Antigens are presented by APCs as antigenic peptides, which are recognized by the T-cell receptor (TCR; Signal 1). The second signal (Signal 2) is delivered when B7 (CD80 and CD86) on the APCs engage CD28 on the T cells 
the mechanistic targets of rapamycin (mTOR), the activation of $\mathrm{Bcl}-\mathrm{Xl}$, the production of interleukin (IL)-2, and the activation of nuclear factor- $\mathrm{kB}$ as well as inhibits protein synthesis and cell growth. In addition, PI3K/Akt signaling pathway blockage degrades transcription factor FoxO1, which binds to the promoter site of PD-1 and increases its expression [31, 62].

The protein crystal structures of the PD-1/PD-L1 complex reveal that their interactions use large, hydrophobic surfaces of the extracellular domains [53]. Within the complex, PD-1 and PD-L1 are almost perpendicular to each other, facilitating interactions through the majority of the surface of their "front" strands. Currently, there are three identified hotspots on PD-L1 (Fig. 2). Two of three hotspots are regarded as drug binding pockets. The first hotspot is a classic pocket with a hydrophobic domain, which includes amino acid residues LTyr56, LGlu58, LArg113, LMet115, and LTyr123. This hotspot has a favorable size to accommodate an aromatic six-membered ring. The second hotspot with LMet115, LAla121, and LTyr 123 residues can be effectively occupied by a branched aliphatic moiety, which can anchor with a terminal hydrogen bond donor moiety at the carbonyl oxygen of LAla121. The third hotspot is an extended groove formed by the main chain and the side chains spanning residues LAsp122 to LArg125, and is flanked by the side

a

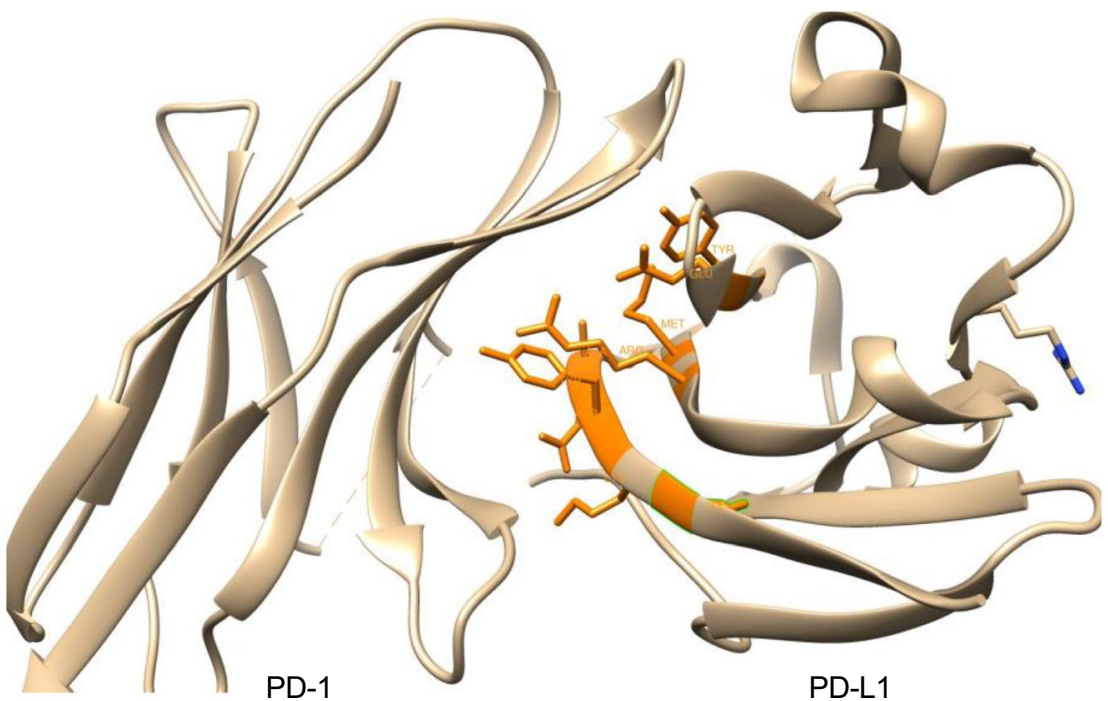

b

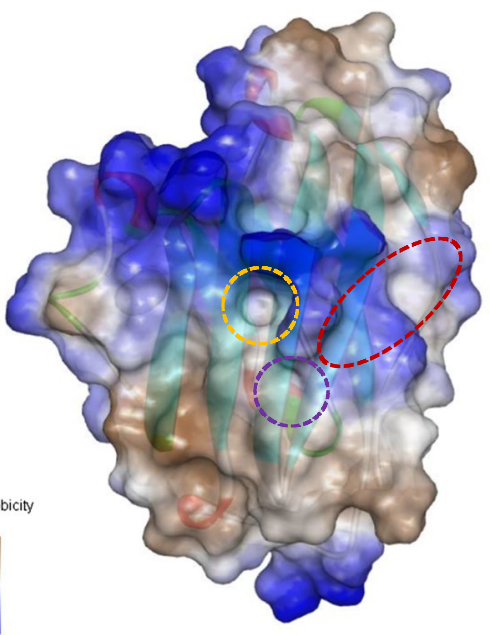

Comprised residues

LTyr56, LGlu58, LArg113, LTyr123, and LMet115

LMet115, LAla121, and LTyr123

LAsp122, LTyr123, LLys124, LArg124, and LAsp126

Fig. 2 The structure of PD-L1 (4ZQK) and three main hot spots between PD-1 and PD-L1. a The structures of PD-L1 and PD-1. Amino acid residues in the main hot spots are labeled as orange color. b Three main hot spots are exhibited. The first hotspot includes LTyr56, LGlu58, LArg113, LMet115, and LTyr123. The second hotspot includes LMet115, LAla121, and LTyr123. The third hotspot is an extended groove formed by the main chain and the side chains spanning residues LAsp122 to LArg125, and is flanked by the side chain of LAsp26 
chain of LAsp26. This hotspot can provide multiple hydrogen bond donors/acceptors. However, it has a relatively shallow space, making it a difficult target for inhibitors of protein interactions.

Overall, it is challenging to target the interface of PD-1/ PD-L1 because of its large and flat hydrophobic pockets $\left(1970 \mathrm{~A}^{2}\right)$ as compared to some other druggable proteins with deep hydrophobic pockets [53]. One of the rational designs for the discovery of PD-1/PD-L1 inhibitors is to evaluate the interactions between the leading compounds and these drug binding pockets using computational based screening methods, which can be further validated by in vitro and in vivo bioassays to eliminate false positive "hits".

\section{Current methodologies for the development of PD-1/PD-L1 inhibitors}

Over the past decades, considerable research efforts have been dedicated to the development of small molecule inhibitors against PD-1/PD-L1 immune checkpoints [64-66]. Biophysical and biochemical assays along with cell-based assays have been developed to identify and evaluate the binding affinity between these inhibitors and PD-1/PD-L1, and their blockage effects toward PD-1/ PD-L1 interactions. A workflow for screening potential inhibitors of PD-1/PD-L1 is shown in Fig. 3.

Binding affinity is one of the most critical parameters to measure the capacity of potential inhibitors binding to PD-1/PD-L1 proteins. PD-1/PD-L1 interactions can be characterized by a series of methods summarized in this review. These biophysical methods are usually performed at the protein level. Although these methods may lead to indefinite parameters regarding the dissociation constant $\left(K_{D}\right)[53,55,67,68]$, binding affinity measurement is still usually required to identify small molecule inhibitors against PD-1/PD-L1.

\section{Surface plasmon resonance (SPR)}

SPR is an optical biosensor technology based on the evanescent wave phenomenon to measure changes in the refractive index of biosensor [69]. The light generated by the light source hits the biosensor and prism. Analyte flows through the channel and binds to the target protein, leading to a shift in the refractive index of the biosensor. The interactions between analyte and proteins are monitored in a real-time manner and the amount of bound proteins and rates of association and dissociation are measured with high precision. SPR is widely used for determining intermolecular interactions. PD-1/PD-L1 interactions are based on their extracellular domains and their interactions include hydrophobic and polar effects. Small molecule inhibitors with blockage effects against PD-1/PD-L1 interactions bind to their extracellular interface. Therefore, SPR is an ideal tool to measure the binding affinity between inhibitors and PD-1/PD-L1. SPR can also determine the real-time kinetic constants between inhibitors and PD-1/PD-L1, which requires the immobilization of PD-1/PD-L1 protein on certain biosensors. His-tagged and tag-free PD-1/PD-L1 have been widely immobilized on the biosensors using amine coupling methods $[44,65]$. For instance, Yang and colleagues developed an SPR technology-based screening method that has successfully screened caffeoylquinic acids as PD-1/PD-L1 inhibitors by immobilizing tag-free PD-1/ PD-L1 extracellular fragment on the CM5 biosensor chip [65]. An advantage of SPR is that no modification is required for the target proteins as compared to other screening methods including NMR-based AIDA and HTRF.

\section{Biolayer interferometry (BLI)}

BLI, similar to SPR, is a label-free technique monitoring real-time biomolecule interactions [70]. The working mechanism of BLI is similar to SPR as it detects

The Screening Workflow of PD-1/PD-L1 Inhibitors

\begin{tabular}{|c|c|c|c|}
\hline $\begin{array}{c}\text { Binding affinity } \\
\text { assay }\end{array}$ & $\begin{array}{c}\text { Blockage ability } \\
\text { assay }\end{array}$ & $\begin{array}{c}\text { Cell-based } \\
\text { Functional assay }\end{array}$ & $\begin{array}{l}\text { graft model } \\
\text { assay }\end{array}$ \\
\hline $\begin{array}{l}\text { Biophysical methods } \\
\text { including SPR, BLI, } \\
\text { ITC, MST, MDS, } \\
\text { DSF, FPIA, and } \\
\text { NMR to determine } \\
\text { binding parameters }\end{array}$ & $\begin{array}{l}\text { Biochemical } \\
\text { methods } \\
\text { including ELISA and } \\
\text { AlphaLISA to } \\
\text { determine blockage } \\
\text { effects }\end{array}$ & $\begin{array}{l}\text { Bioluminiscence } \\
\text { reporter cell-based } \\
\text { assay and T-cell } \\
\text { based assay to } \\
\text { evaluate biological } \\
\text { functions }\end{array}$ & $\begin{array}{l}\text { Xenograft animal } \\
\text { model to investigate } \\
\text { the anti-tumor effects } \\
\text { and the underlying } \\
\text { mechanisms }\end{array}$ \\
\hline
\end{tabular}

Fig. 3 The screening workflow of PD-1/PD-L1 inhibitors. The identification of PD-1/PD-L1 inhibitors is required by using a series of assays including binding affinity assay, blockage ability assay, cell-based functional assay and xenograft model assay 
the changes of the optical interference patterns on the protein-coated biosensors that are generated by mass changes from the interactions between analyte and protein [70]. Less protein is required for BLI measurement, which facilitates high-throughput screening with great potential to screen small molecule inhibitors against PD-1/PD-L1. Unlike SPR which detects biomolecular interactions under flow conditions, BLI is conducted under non-flow conditions which impair its ability to depict the kinetic profiles.

\section{Isothermal titration calorimetry (ITC)}

ITC is a useful method to characterize the thermodynamic parameters of interactions between analytes and proteins [71]. The binding events are accompanied by changes of enthalpy $(\Delta H)$. Analyte-protein interactions driving the process and parameters including stoichiometry of binding $(\mathrm{n})$, the binding constant $(\mathrm{Ka}), \mathrm{K}_{\mathrm{D}}$, $\Delta H$, and entropy $(\Delta \mathrm{S})$ can be determined. PD-1/PD-L1 interactions exhibit a favorable $\Delta H \mathrm{obs}$ and $\mathrm{T} \Delta \mathrm{S}$ and their binding is driven entropically [53]. However, Pascolutti and colleagues reported that the driving force of wildtype PD-1/PD-L1 exhibits an entropic component [72]. An advantage for ITC measurement is that it does not require immobilization, protein modification, or fluorescent labeling. It is also an approach that can measure all binding parameters in a single assay. However, ITC is not suitable for high throughput screening due to being timeconsuming with high sample consumption.

\section{Microscale thermophoresis (MST)}

MST is a suitable technology for determining the intramolecular interactions with less sample consumption [73]. MST is based on the directed movement of molecules along a microscopic temperature gradient [74]. Changes in their hydration shell, charge, or size can be determined in this process. MST technology requires two binding partners, one is labeled with fluorescence dye and the other one is free-labeled [74]. MST does not require immobilization. Intermolecular interactions can be measured under physicochemical conditions or biological solutions. In addition, protein purification is also not required to access the protein of interest [75]. However, the binding partner labeled with hydrophobic fluorescence may lead to non-specific binding. Consequently, the bias of the results might be observed due to the indiscriminate fluorescent labeling.

MST is applied to determine PD-1/PD-L1 binding affinities [67] whereby cell lysate is extracted from CHO-K1 cells that express PD-1-eGFP or PD-L1-eGFP, to prepare the fluorescently labeled binding partner. PD-L1 or PD-1 protein is used as label-free binding partners. The $K_{D}$ value of $7.2 \mu \mathrm{M} \pm 1.9 \mu \mathrm{M}$ between
hPD-1 and hPD-L1-eGFP is obtained using MST [67], which is similar to SPR assay $\left(K_{D}\right.$ value of $h P D-1 / h P D-$ $\mathrm{L} 1=8.2 \pm 0.1 \mu \mathrm{M})[53,76]$. Therefore, MST technology highlights its potential application for studying the interactions between PD-1/PD-L1 and their inhibitors.

\section{Differential scanning fluorometry (DSF)}

DSF is an excellent screening assay to discover lowmolecular-weight ligands with binding affinities for target proteins by monitoring the amount of the fluorescent dye that binds to the protein [77]. Ligand is added into the solution containing protein and fluorescent dye in the polymerase chain reaction (PCR) microplates. Fluorescent intensities are measured as the temperature is gradually raised by the PCR instrument [78]. The binding of PD-1/PD-L1 inhibitors induces thermal stabilization of PD-1/PD-L1, which is proportional to the inhibitors' affinity [79]. DSF is suitable for high-throughput screening due to the small amount and low concentrations needed for protein binding. However, impurities (e.g. detergent molecules) have to be excluded from the reaction system. In addition, the interactions between fluorescent dye and target proteins may interfere with the detection results. Recently, it was reported that proteins that have already been labeled with green fluorescent can be applied to avoid the interactions with the fluorescent dye [80].

\section{Fluorescence polarization immunoassay (FPIA)}

FPIA is based on the principle of fluorescence anisotropy. As a homogenous assay, it determines the rotational and translational motion of excited fluorescent molecules in the reaction mixture [81]. It is a rapid and quantitative method to detect several biomolecular interactions and enzyme activities. This assay is a feasible mix-and-read method with fewer reagents required, which is suitable for high-throughput screening of peptides or nucleotide sequences binding to PD-1/PD-L1. For instance, it has been successfully demonstrated that FPIA can be applied to analyze the affinity between self-inhibitory peptides (refers to peptides disrupting the PD-1/PD-L1 complex formation) and PD-1 [82]. A major disadvantage of FPIA is that the protein-protein interactions containing extensive interfaces can lead to low sensitivity for detecting biomolecules that are disproportionately important for the affinity of the interactions. In this case, competitive binding assays with specific fluorescence polarization probes can be applied to study the interactions between the molecules (e.g. PD-1/PD-L1 inhibitor) and their featured interfaces $[83,84]$. 


\section{Nuclear magnetic resonance (NMR)}

NMR is a powerful tool to determine the structure, dynamics, and biomacromolecule interactions. NMR can also detect the binding affinities of protein targets with small molecules that have a broad affinity range $[85,86]$. It can detect weak intermolecular interactions, which makes it a valid screening tool for low-affinity fragments [86]. However, binary screening NMR does not give information on whether the small molecules can exert blockage effects on protein-protein interactions. To overcome this limitation, Musielak and colleagues described an NMR competitive assay, termed as weakantagonist induced dissociation assay-NMR (w-AIDANMR). In this competitive assay, lead compounds with capacity of dissociating protein-protein interactions are depicted by the strength of their binding affinities with protein components involved in the protein-protein interactions $[85,87]$. The $\mathrm{K}_{\mathrm{D}}$ value of PD-1/PD-L1 complex is approximately $8 \mu \mathrm{M}$, which might be too strong for the NMR-based screening for "weak" fragments, as these fragments exhibit lower affinities with 2 to 3 orders of magnitude. Therefore, instead of using PD-1, PD-1 mutant can be applied to estimate the $K_{D}$ value of fragments with PD-1/PD-L1. The $\mathrm{K}_{\mathrm{D}}$ values between fragments and PD-L1 by using w-AIDA-NMR method are similar to the corresponding data from the HTRF assays, supporting the reliability of the w-AIDA-NMR method. In addition, some small molecule PD-L1 inhibitors that block the PD-1/PD-L1 interactions have also been characterized using AIDA NMR [64, 88, 89]. Interestingly, a combination of AIDA-NMR, PD-1/PD-L1 structurebased design, and fragment merging approaches creates novel chemotypes as a starting point for the development of small molecule inhibitors against PD-1/PD-L1 [88]. Recently, high-field NMR spectrometers have been developed to improve the NMR's sensitivity and resolution [90], which highlights the potential application of NMR-based methods in large-scale screening.

\section{The enzyme-linked immunosorbent assay (ELISA) and alphaLISA}

ELISA is a solid-phase type of enzyme immunoassay to detect the presence of proteins using antibodies against the proteins to be measured [91]. Because PD-L1 has a strong binding affinity with PD-1, PD-1/PD-L1 pair ELISA can be applied for screening small molecules with blockage effects towards PD-1/PD-L1 interactions. Briefly, PD-1 or PD-L1 protein (or PD-1/PD-L1 extracellular domain) is coated by incubation with biotin labelled-PD-L1 or PD-1 with or without the small molecules of interest. Next, streptavidin-horseradish peroxidase and colorimetric horseradish peroxidase substrates are added. The inhibitory abilities of small molecules towards PD-1/PD-L1 interactions are determined by comparing the optical density values among the experimental groups. Although ELISA is a widely used detection platform for PD-1/PD-L1 inhibitors, it requires multiple procedure steps (e.g. washes) with a relatively narrow dynamic range (typically 2 logs). Therefore, more than one sample dilution is required, which makes PD-1/ PD-L1 pair ELISA less feasible to adapt for high-throughput screening.

Alternatively, AlphaLISA is a homogeneous immunoassay that can be used to screen for PD-1/PD-L1 inhibitors in a high-throughput manner [92]. AlphaLISA is a bead-based immunoassay without the requirement of 'wash.' Therefore, it avoids washing times thereby reducing the total assay time as compared to ELISA. The principle of the AlphaLISA method is based on luminescent oxygen-channeling chemistry. AlphaLISA consists of donor beads and acceptor beads. Streptavidin-coated donor beads are used to bind biotinylated-PD-L1, and anti-His acceptor beads are used to bind to His-tagged PD-1. Donor beads and acceptor beads interact with each other due to the strong binding affinity between PD-1 and PD-L1. Donor beads contain a photosensitizing agent that can be illuminated by a wavelength of $680 \mathrm{~nm}$ generating singlet oxygen, which initiates a cascade reaction with the acceptor beads. Consequently, the acceptor beads will generate a remarkable signal amplification (at $615 \mathrm{~nm}$ ) by singlet oxygen released from the donor beads. Small sample volumes $(1-5 \mu \mathrm{L})$ with high sensitivity and wide dynamic ranges (typically 3 logs) are required in the AlphaLISA assay. Therefore, it is an ideal platform for high-throughput screening.

\section{Bioluminescent reporter cell-based assay}

Bioluminescent reporter cell-based assay, which consists of two engineered cell lines including PD-1 effector cell line and PD-L1 aAPC/CHO-K1 cell line, can be used for screening the PD-1/PD-L1 inhibitors [93]. PD-1 effector cell line is constructed on Jurkat $T$ cell line that stably expresses PD-1 by transfection of luciferase reporter plasmids containing NFAT response element. PD-L1 aAPC/CHO-K1 cell line is constructed on CHO-K1 cell line that expresses PD-L1 by engineering cell surface proteins to activate cognate TCRs without antigen. In the co-culture system, PD-1 binds to PD-L1 and subsequently suppresses the TCR signaling and luminescence mediated by NFAT response element. The presence of PD-1/PD-L1 inhibitors blocks the PD-1/PD-L1 interactions, leading to the reactivation of TCR signaling and luminescence. Quantification of TCR activation with or without PD-1/PD-L1 inhibitors is measured by the intensity of luciferase activity. In addition, the NF- $\mathrm{kB}$ reporter assay is an alternative option for the NFAT response 
element reporter system. However, it is preferable to use the NFAT response element reporter system because the NF- $\mathrm{kB}$ signaling is a less specific marker of the CD3 dependent $T$ cell activation that can be activated by other stimuli7 $[94,95]$.

Unlike the other aforementioned biophysical and biochemical assays that cannot evaluate the functional impact of small molecules on PD-1/PD-L1 interactions, bioluminescent reporter cell-based assay has an advantage of assessing the biological functions of PD-1/PD-L1 inhibitors by measuring the activation of NFAT signaling pathway. In addition, this commercialized assay is a labor- and time-efficient tool, which is suitable for high-throughput screening. Moreover, bioluminescent reporter cell-based assay has less variation as compared to primary cell-based assays [96]. However, the current bioluminescent reporter cell-based assays cannot provide information of antigen-specific or multiparametric interactions. Due to PD-1/PD-L1 mediated downstream signaling transductions involved in many proteins [31], the bioluminescent reporter cell-based assay is insufficient to evaluate the functions of PD-1/PD-L1 inhibitors on the signaling transduction-related proteins.

\section{T cell-based assay}

Although a cell-free assay system can be used to evaluate the basic biological functions of PD-1/PD-L1 inhibitors, further biological effects of leading inhibitors on PD-1/ PD-L1's physiological properties, including their subcellular localization, or functional changes upon stimulation, might not be evaluated sufficiently with cell-free assays alone. To evaluate the bioactivities and complicated physiological functions of PD-1/PD-L1 inhibitors, $T$ cell-based assays are often used.

$\mathrm{T}$ cell-based assays consist of effector cells expressing PD-1, cells presenting PD-L1, and the activation signal (CD3 activator) for effector cells. Several methods for the development of inhibitors targeting PD-1/PD-L1 using T cell-based assays have been reported [47]. The activation of CD3 (Signal 1) is an essential step for the activation of PD-1 effector cells in this assay. The TCR/CD3 can be expressed by the effector cells and activated by several biological components including peptide/MHC complex on the target cells, superantigen in the presence of APCs expressing MHC II, soluble CD3 $\varepsilon$ antibodies, and activator cells expressing transmembrane aCD3e. In the $\mathrm{T}$ cell-based assays, tumor cells or target cells expressing tumor-associated antigen are often used [97]. In these assays, the presence of effector cells express tumorassociated antigen-specific CAR containing the $\mathrm{CD} 3 \zeta$ signaling domain, or TCR/CD3 effector cells with CD3 antibodies and tumor-associated antigen antibodies, leads to the dependent activation of CD3 in the effector cells.

In the $\mathrm{T}$ cell-based assays, immobilized cell lines are preferable to avoid issues with accuracy and reproducibility associated with primary cells $[98,99]$. For instance, the immobilized Jurkat human $\mathrm{T}$ cell line, a commonly used $\mathrm{T}$ cell line, has been successfully developed to measure the CD3 dependent $T$ cell activation [100]. In addition, the Jurkat human $\mathrm{T}$ cell line is suitable for genetic engineering, which can be applied for evaluating the biological effects of small molecules targeting PD-1. Versteven and colleagues developed an antigen-specific and high-throughput $\mathrm{T}$ cell-based assay by using a genetically modified TCR-deficient Jurkat $\mathrm{T}$ cell line that is also transduced with PD-1 plasmid [101].

$\mathrm{T}$ cell-based assays are widely used to evaluate the blocking abilities and biological functions of PD-1/PD-L1 inhibitors [102]. Although the binding abilities of small molecule inhibitors against PD-1/PD-L1 are usually analyzed by biophysical and biochemical assays, $\mathrm{T}$ cell-based assays are also used to evaluate their blocking abilities based on flow cytometry method [103]. To evaluate the blocking abilities of PD-1/PD-L1 small molecule inhibitors, cell co-culture based assays or single-type cell incubated with PD-1 or PD-L1 proteins are often used. For instance, small molecule inhibitors can be incubated in a co-culture system with $\mathrm{T}$ cells expressing PD-1 and APCs/tumor cells expressing PD-L1. The blocking abilities of small molecule inhibitors can be evaluated by measuring PD-1/PD-L1 expression using flow cytometry [104]. Similarly, in a single-type cell incubated with PD-1 or PD-L1 protein, the blocking affinity of small molecule inhibitors against PD-1 or PD-L1 protein is measured by the qualification of fluorescence intensity.

The primary aim for using $\mathrm{T}$ cell-based assay is to verify the biological functions of $\mathrm{PD}-1 / \mathrm{PD}-\mathrm{L} 1$ inhibitors. In the tumor microenvironment, overexpression of PD-1 leads to $\mathrm{T}$ cell dysfunction, whereas PD-1/ PD-L1blockage reactivates $T$ cell's biological functions [105]. The functional assays need a co-culture system consisting of PD-1 expressing cells and PD-L1 expressing cells. It is based on the change of $\mathrm{T}$ cell dysfunction in the presence of small molecules targeting $\mathrm{PD}-1 / \mathrm{PD}-\mathrm{L} 1$. The functional assays of $\mathrm{T}$ cells include measurements of cell proliferation, $\mathrm{T}$ cell-related cytokine release (IL-2 and interferon (IFN)- $\gamma$ ), and the change of PD-1 downstream events including signaling proteins and their phosphorylation [106]. For instance, low proliferative capacity is a key character of $\mathrm{T}$ cell dysfunction [54], and cell proliferation is one of the most used assays to evaluate the biological functions of PD-1/PD-L1 inhibitors. In addition, the detection of IL-2 and IFN- $\gamma$ are also widely used in the functional 
assay as IL-2 and IFN- $\gamma$ are essential for T cell proliferation and activity, respectively [107, 108]. Furthermore, signaling proteins involved in the PD-1/PD-L1 axis-mediated signaling transductions can be investigated to evaluate the biological effects of PD-1/PD-L1 inhibitors.

\section{Natural product-derived PD-1/PD-L1 inhibitors}

Most $\mathrm{mAbs}$ have inherent shortcomings including limited permeability, irAEs, immunogenicity, and high cost, as compared to small molecules derived PD-1/ PD-L1 inhibitors $[109,110]$. Small molecule inhibitors usually have less side effects, shorter biological halflife, and are less expensive with easier administration routes. Several published review articles have summarized the advantages of various synthetic small molecule PD-1/PD-L1 inhibitors [64, 66, 111]. Recently, several natural product-derived small molecules with blockage effects against PD-1/PD-L1 interactions have been reported. Instead of elaborating on all current small molecule inhibitors, herein we summarize natural product-derived PD-1/PD-L1 inhibitors with an emphasis on the screening methodologies that were applied for their identification.

\section{Macrocyclic compounds}

\section{Gramicidin derivatives from Bacillus brevis}

Gramicidin $S$ is a natural decacyclopeptide consisting of two repeating pentapeptides as cyclo(-Val-Orn-LeuD-Phe-Pro-)2, which imposes a unique amphiphilic structure with hydrophilic and hydrophobic residues on the opposing side of cyclopeptide plane ring. Sun and co-workers hypothesized that gramicidin S's amphiphilic structure can be complementary to the interface of PD-L1/PD-L1 thereby facilitating their binding capacity [112]. An in vitro binding assay (HTRF) was determined to evaluate the blockage efficacy of cyclopeptides towards PD-L/PD-L1 binding and gramicidin S exhibited a weak blockage efficacy of $6.86 \%$. They further chemically synthesized a series of cyclopeptides using the skeleton of gramicidin S [112]. Among the synthesized gramicidin S derivatives, Cyclo(-Leu-DTrp-Pro-Thr-Asp-LeuDPheLys(Dde)-Val-Arg (Fig. 4) exhibits the most potent blockage efficacy of $95.8 \%$ at $20 \mu \mathrm{M}$ against PD-1/PD-L1 interactions. It had the lowest $\mathrm{IC}_{50}$ value of $1.42 \mu \mathrm{M}$ against PD-1/PD-L1 interactions based on the co-immunoprecipitation assay. Co-administration of Cyclo(-LeuDTrp-Pro-Thr-Asp-Leu-DPheLys(Dde)-Val-Arg (40 mg/ $\mathrm{kg}$ ) by intraperitoneally injection (ip) with anti-CD8 antibody suppressed the tumor volume (54.8\%) and tumor

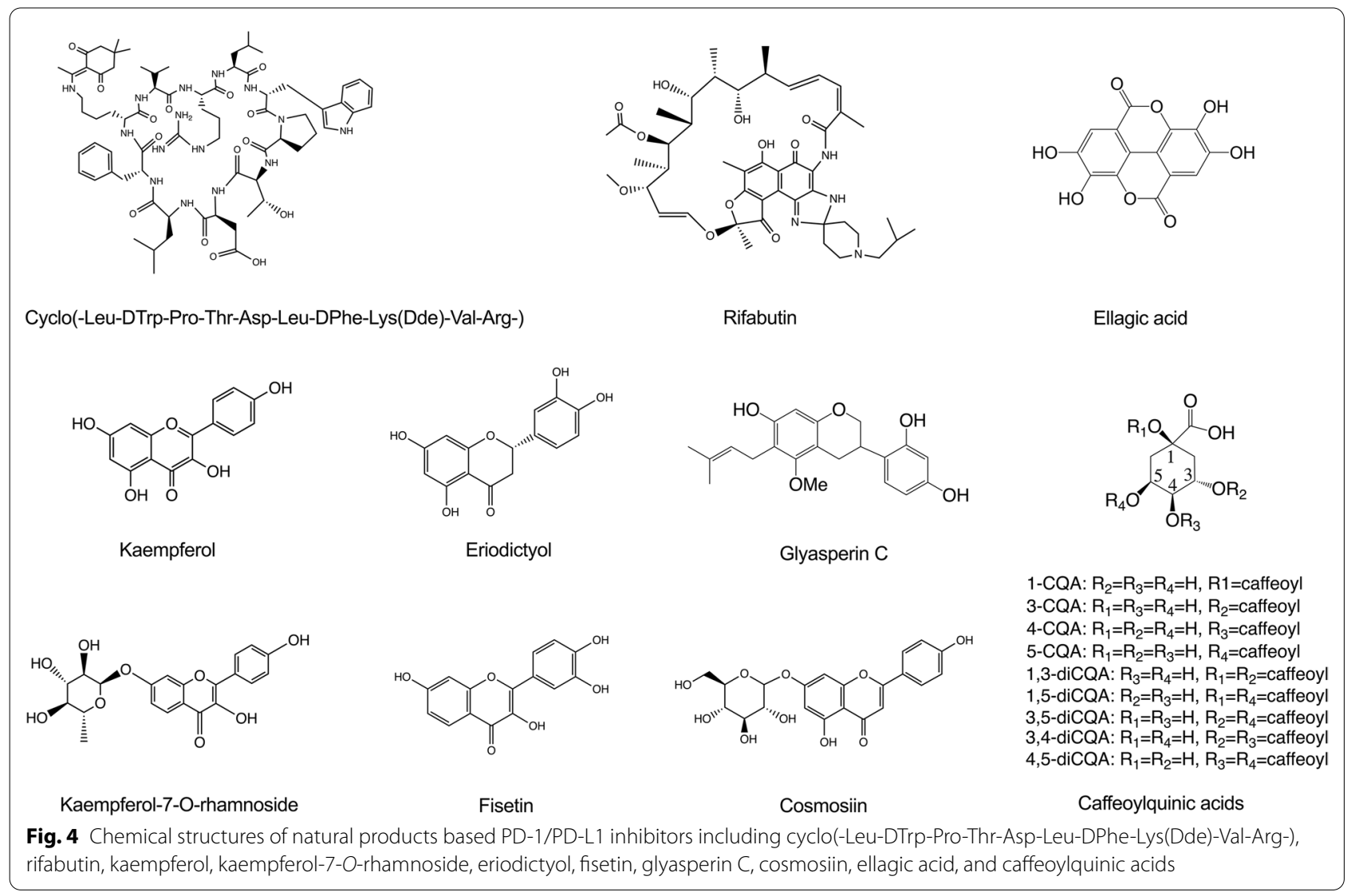


weight (64.9\%) in a B16F10 tumor bearing animal model. Immunohistochemistry staining showed that treatment with Cyclo(-Leu-DTrp-Pro-Thr-Asp-Leu-DPheLys(Dde)Val-Arg enhanced the percentage of CD3+ T cells and $\mathrm{CD} 8+\mathrm{T}$ cells in the tumor tissues. In addition, the binding properties of the most promising cyclopeptide were well characterized using a panel of biochemical, biophysical, and cell-based assays including SPR, Western blotting (WB), NMR, circular dichroism (CD), co-immunoprecipitation, and molecular docking. The key findings in this study are summarized in Table 1.

\section{Ansamycin antibiotic}

Patil et al. used an AlphaLISA assay to screen the inhibitory effects of FDA-approved macrocyclic drugs against PD-1/PD-L1 interactions [113]. A collection of 20 macrocyclic compounds including actinomycin $\mathrm{D}$, amphotericin $\mathrm{B}$, bacitracin, bryostatin, candicidin, clarithromycin, cyclosporin A, cyanocobalamin, erythromycin, everolimus, geldanamycin, ivermectin B1a, macbecin, metocurine, monocrotaline, nystatin, plerixafor, rifampin, sirolimus, and troleandomycin was screened at a concentration of $50 \mu \mathrm{M}$ using the AlphaLISA assay. Among these macrocyclics, only rifampin (Fig. 4), an ansamycin type of antibiotic, effectively blocked the interactions between PD-1 and PD-L1 (blockage efficacy $=47.9 \%$ ) whereas the other compounds were less effective (blockage efficacy $<20 \%$ ). Four additional rifampin analogs including rifabutin, rifapentine, rifamycin SV, and 3-formyl rifamycin were selected for further evaluation. Rifampin analogs $(50 \mu \mathrm{M})$ showed promising blockage efficacy ranging from 24 to $66.7 \%$, in which rifabutin was the most active macrocyclic antibiotic with an $\mathrm{IC}_{50}$ value of $25 \mu \mathrm{M}$ (Table 1). In addition, molecular docking demonstrated that rifabutin is able to form a stable ligand-protein complex facilitated by several molecular forces including $\pi-\pi$ stacking interaction and hydrogen bonding. However, binding affinities between these ansamycin antibiotics and PD-1/PD-L1 proteins are not reported.

\section{Phenolic compounds}

\section{Kaempferol and kaempferol-7-O-rhamnoside}

Kaempferol and its glycosides including kaempferol3,7-dirhamnoside and kaempferol-7-O-rhamnoside, are flavonoids from Geranium thunbergia (Geranii Herba extract) with reported antitumor activities [114]. In vitro assays were used to demonstrate that kaempferol and kaempferol-7-O-rhamnoside are able to block PD-1/ PD-L1 interactions. Competitive ELISA assays were used to measure the inhibitory effects of kaempferol and kaempferol-7-O-rhamnoside (Fig. 4) on the PD-1/PD-L1 interactions, which were supported by cell co-culture
(Jurkat $\mathrm{T} / \mathrm{CHO}-\mathrm{K} 1$ cells) assay. The $\mathrm{EC}_{50}$ values of kaempferol and kaempferol-7-O-rhamnoside were 16.46 and $15.37 \mu \mathrm{M}$, respectively, against PD-1/PD-L1 interactions in a dose-dependent manner. The direct binding between kaempferol and PD-1 or PD-L1 were measured by obtaining the binding kinetics including the $\mathrm{K}_{\mathrm{D}}$, $\mathrm{ka}$, and $\mathrm{kd}$ using BLI and SPR technologies. In addition, a computational-based approach was used to map the binding site of kaempferol and kaempferol-7-O-rhamnoside on PD-1 or PD-L1 and calculate the binding energy between the ligands and proteins.

\section{Apigenin and cosmosiin from Salvia plebeia}

Choi et al. reported that Salvia plebeia R. Br. extract (SPE) blocked the interactions between PD-1 and PD-L1 [115]. Two flavonoids including apigenin and cosmosiin (Fig. 4) from SPE showed blockage effects against the interactions between PD-1 and PD-L1 in a cell-based assay (aAPC/CHO-K1 cells) and a competitive ELISA assay. PD-L1 aAPC/CHO-K1 cell co-culture based assay demonstrated that $\mathrm{EC}_{50}$ values of SPE and SPE-ethyl acetate fraction were $27.2 \mathrm{mg} / \mathrm{mL}$ and $1.08 \mathrm{mg} / \mathrm{mL}$, respectively, against $\mathrm{PD}-1 / \mathrm{PD}-\mathrm{L} 1$ interactions. In addition, cosmosiin, identified as the strongest PD-1/PD-L1 inhibitor among 7 SPE fractions, was able to directly bind to PD-1 and PD-L1 with a $\mathrm{K}_{\mathrm{D}}$ value of 386 and $85 \mu \mathrm{M}$, respectively, in the BLI assay. Computational docking was then determined to predict cosmosiin's binding capacity to PD-1 and PD-L1, showing a binding energy of -6.2 and $-5.8 \mathrm{kcal} / \mathrm{mol}$, respectively (Table 1 ). Moreover, the inhibitory effect of SPE on PD-1 and PD-L1 was further supported by in vivo assays using a humanized PD-L1 knock-in MC38 tumor-bearing animal model. Treatment of SPE at doses of 100 and $300 \mathrm{mg} / \mathrm{kg}$ exhibited tumor inhibition rates of 44.9 and $77.8 \%$, respectively, in a dosedependent manner on day 16. In addition, treatment of SPE $(300 \mathrm{mg} / \mathrm{kg})$ enhanced the infiltration of CD8+ T cells in the tumor tissues.

\section{Eriodictyol and fisetin from Rhus verniciflua Stokes extract}

$\mathrm{Li}$ and colleagues screened 800 herbal extracts for the PD-1/PD-L1 inhibition capacity, which led to the identification of Rhus verniciflua Stokes extract as an active inhibitor using competitive ELISA [116]. Four phenolic compounds including eriodictyol, fisetin, quercetin, and liquiritigenin were isolated from the Rhus verniciflua Stokes extract with PD-1/PD-L1 blocking effect. Eriodictyol and fisetin showed the most potent inhibitory effect in the competitive ELISA with an $\mathrm{IC}_{50}$ value of 0.04 and $0.4 \mu \mathrm{M}$, respectively. However, the binding affinity between eriodictyol or fisetin and PD-1/PD-L1 was not reported. 
Table 1 A summarize of natural product-derived PD-1/PD-L1 inhibitors

\begin{tabular}{|c|c|c|c|c|}
\hline \multicolumn{3}{|l|}{ Natural products } & \multirow[t]{2}{*}{ Methodology } & \multirow[t]{2}{*}{ Key finding(s) } \\
\hline Name & Type & Sub-type & & \\
\hline Amphotericin B & Macrocyclic & Macrolide & AlphaLISA; MD & Not active \\
\hline Bacitracin & & Cyclic peptide & & \\
\hline Everolimus & & Macrolide & & \\
\hline Clarithromycin & & Macrolide & & \\
\hline Cyclosporin A & & Cyclic peptide & & \\
\hline Actinomycin D & & Cyclic peptide & & Weak PD1/PD-L1 inhibitor (less than 20\% inhibition at \\
\hline Cynocobalamin & & Porphyrin & & \\
\hline Bryostatin & & Macrolide & & \\
\hline Candicidin & & Macrolide & & \\
\hline Geldanamycin & & Polyketide & & \\
\hline Ivermectin B1a & & Macrolide & & \\
\hline Macbecin & & Ansamycin & & \\
\hline Metocurine & & Alkaloid & & \\
\hline Monocrotaline & & Alkaloid & & \\
\hline Nystatin & & Macrolide & & \\
\hline Plerixafor & & Bicyclam & & \\
\hline Sirolimus & & Macrolide & & \\
\hline Troleandomycin & & Macrolide & & \\
\hline Rifampin & & Ansamycin & & PD1/PD-L1 inhibition was $47.9 \%$ at $50 \mu \mathrm{M}$ \\
\hline Rifabutin & & & & $\begin{array}{l}\text { PD1/PD-L1 inhibition was } 66.7 \% \text { at } 50 \mu \mathrm{M} \\
\mathrm{IC}_{50} \text { was } 25 \mu \mathrm{M}\end{array}$ \\
\hline Rifapentine & & & & PD1/PD-L1 inhibition was $52.1 \%$ at $50 \mu \mathrm{M}$ \\
\hline Rifamycin SV & & & & PD1/PD-L1 inhibition was $34.5 \%$ at $50 \mu \mathrm{M}$ \\
\hline Formyl rifamycin & & & & PD1/PD-L1 inhibition was $40.2 \%$ at $50 \mu \mathrm{M}$ \\
\hline Rifaximin & & & & PD1/PD-L1 inhibition was $24.0 \%$ at $50 \mu \mathrm{M}$ \\
\hline Gramicidin S & Macrocyclic & Cyclic peptide & HTRF; NMR; SPR; CD; MD & PD1/PD-L1 inhibition was $6.86 \%$ at $20 \mu \mathrm{M}$ \\
\hline Gramicidin $\mathrm{S}$ derivative & & & & $\begin{array}{l}\mathrm{PD} 1 / \mathrm{PD}-\mathrm{L} 1 \text { inhibition was } 95.8 \% \text { at } 20 \mu \mathrm{M} ; \mathrm{IC}_{50} \text { was } \\
1.42 \mu \mathrm{M} \\
\text { Conserved the } \beta \text {-sheet conformation of the gramicidin } \\
\text { S skeleton } \\
K_{\mathrm{D}} \text { was } 1.66 \mathrm{mM} \text { and } 5.67 \mu \mathrm{M} \text { for PD-1 and PD-L1, } \\
\text { respectively }\end{array}$ \\
\hline Kaempferol & Phenolic & Flavonoid & $\begin{array}{l}\text { ELISA; BLI; SPR } \\
\text { Cell based assay } \\
\text { MD }\end{array}$ & $\begin{array}{l}\mathrm{IC}_{50} \text { for blocking PD-1/PD-L1 was } 7.797 \mu \mathrm{M} \\
\text { Cellular PD-1/PD-L1 inhibition IC } \mathrm{C}_{50} \text { was } 14.46 \mu \mathrm{M} \\
\text { Calculated binding energy was }-5.4 \text { and }-5.0 \mathrm{kcal} / \mathrm{mol} \\
\text { for PD-1 and PD-L1, respectively }\end{array}$ \\
\hline Kaempferol-7-O-rhamnoside & & Flavonoid & & $\begin{array}{l}\text { Cellular PD-1/PD-L } 1 \text { inhibition } \mathrm{IC}_{50} \text { was } 14.46 \mu \mathrm{M} \\
K_{\mathrm{D}} \text { was } 31.1 \text { and } 19.7 \mu \mathrm{M} \text { for PD-1 and PD-L1, respec- } \\
\text { tively } \\
\text { Calculated binding energy was }-5.6 \text { and }-5.3 \mathrm{kcal} / \mathrm{mol} \\
\text { for PD-1 and PD-L1, respectively }\end{array}$ \\
\hline Cosmosiin & Phenolic & Flavonoid & $\begin{array}{l}\text { ELISA; BLI } \\
\text { Cell based assay } \\
\text { MD }\end{array}$ & $\begin{array}{l}\text { Increased T-cell functional activity by } 1.91 \text {-fold; Had } \\
K_{D} \text { value of } 386 \text { and } 85 \mu \mathrm{M} \text { for PD- } 1 \text { and PD-L1, } \\
\text { respectively } \\
\text { Fit to a } 1: 1 \text { binding model to PD- } 1 \text { and PD-L1; Had a } \\
\text { predicted binding affinity of }-6.2 \text { and }-5.8 \mathrm{kcal} / \mathrm{mol} \\
\text { for PD-1 and PD-L1, respectively }\end{array}$ \\
\hline Apigenin & & Flavonoid & & Increased T-cell functional activity by 2.03 -fold \\
\hline Eriodictyol & Phenolic & Flavanone & ELISA & Had an $I_{50}$ of $0.04 \mu \mathrm{M}$ for PD-1/PD-L1 \\
\hline Fisetin & & Flavonol & & Had an $I_{50}$ of $0.04 \mu \mathrm{M}$ for PD-1/PD-L1 \\
\hline Glyasperin C & Phenolic & Isoflavan & HTRF & Had an PD-1/PD-L1 inhibition rate of $64.3 \%$ at $100 \mu \mathrm{M}$ \\
\hline
\end{tabular}


Table 1 (continued)

\begin{tabular}{|c|c|c|c|c|}
\hline \multicolumn{3}{|l|}{ Natural products } & \multirow[t]{2}{*}{ Methodology } & \multirow[t]{2}{*}{ Key finding(s) } \\
\hline Name & Type & Sub-type & & \\
\hline Caffeoylquinic acid & \multirow[t]{4}{*}{ Phenolic } & - & \multirow[t]{4}{*}{ SPR } & $K_{D}=1.24 \times 10^{-5} \mathrm{M}$ for PD-1; not detected for PD-L1 \\
\hline 3-O-caffeoylquinic acid & & Caffeoylquinic acid & & $K_{D}=1.95 \times 10^{-6} \mathrm{M}$ for PD- $1 ; 1.71 \times 10^{-5} \mathrm{M}$ for PD-L1 \\
\hline 4-O-caffeoylquinic acid & & Caffeoylquinic acid & & $K_{D}=5.07 \times 10^{-6} \mathrm{M}$ for PD-1; not detected for PD-L1 \\
\hline 5-O-caffeoylquinic acid & & Caffeoylquinic acid & & $K_{D}=1.68 \times 10^{-5} \mathrm{M}$ for PD-1; $8.13 \times 10^{-5} \mathrm{M}$ for PD-L1 \\
\hline Ellagic acid & Phenolic & - & $\begin{array}{l}\text { ELISA } \\
\text { WB } \\
\text { Cell based assay }\end{array}$ & $\begin{array}{l}\text { Blocked PD-1/PD-L1 binding with an } \mathrm{IC}_{50} \text { value of } \\
22.92 \mu \mathrm{g} / \mathrm{mL} \\
\text { Bound to PD-1 and PD-L1 in WB; }\end{array}$ \\
\hline ZINC 67,902,090 & \multirow[t]{2}{*}{ Heterocyclic } & \multirow[t]{2}{*}{ Pyrrolidine-oxadiazole } & \multirow{2}{*}{$\begin{array}{l}\text { AlphaLISA } \\
\text { WB } \\
\text { MD }\end{array}$} & $\begin{array}{l}\text { PD-1/PD-L1 inhibition potency was } 30 \% \text { as compared } \\
\text { to BMS-202 }\end{array}$ \\
\hline ZINC 12,529,904 & & & & $\begin{array}{l}\text { PD-1/PD-L1 inhibition potency was } 40 \% \text { as compared } \\
\text { to BMS-202 }\end{array}$ \\
\hline
\end{tabular}

\section{Glyasperin C from Glycyrrhiza uralensis}

Bao et al. reported the isolation of a flavonoid, glyasperin C (Fig. 4), from Glycyrrhiza uralensis and its PD-1/PD-L1 inhibitory effect using a commercially available homogeneous time resolved fluorescence (HTRF) assay [117]. The isolated compounds showed PD-1/PD-L1 inhibition ratios ranging from 30 to $65 \%$ at $100 \mu \mathrm{M}$.

\section{Ellagic acid from black raspberry (Rubus coreanus Miquel) extract}

Kim et al. reported that a black raspberry (Rubus coreanus Miquel) extract (RCE) interrupted the binding of PD-1 and PD-L1 with an $\mathrm{IC}_{50}$ value of $83.8 \pm 4.7 \mu \mathrm{g} /$ $\mathrm{mL}$ in the competitive ELISA assay [118]. PD-L1 aAPC/ CHO-K1 cell co-culture based assay revealed that RCE increased the production of IL-2 by 1.8-fold with an $\mathrm{EC}_{50}$ value of $56.15 \pm 14.35 \mu \mathrm{g} / \mathrm{mL}$, as compared to the control group. The inhibitory effect of RCE on PD-1/PD-L1 interaction was further supported by in vivo data using a humanized PD-L1 knock-in MC38 tumor-bearing animal model, in which oral administration of RCE (50 and $100 \mathrm{mg} / \mathrm{kg} /$ day) exhibited tumor inhibition rates of $66.94 \%$ and $73.81 \%$, respectively, on day 21 . In addition, the major phytochemical in RCE was identified as ellagic acid (Fig. 4) and its effects on PD-1 and PD-L2 interaction were evaluated using in vitro assays including competitive ELISA, WB pull-down, and cell-based assays (PD-1 Jurkat effector cell/ PD-L1 CHO-K1 cell). Ellagic acid was shown to block PD-1/PD-L1 interaction in a concentration-dependent manner with an $\mathrm{IC}_{50}$ value of $22.92 \mu \mathrm{g} / \mathrm{mL}$ (Table 1). In addition, ellagic acid-conjugated sepharose 4B beads pull-down assay showed that ellagic acid was able to directly bind PD-1 and PD-L1 and interrupt their binding capacity [118].

\section{Caffeoylquinic acid derivatives}

Caffeoylquinic acid and its derivatives (Fig. 4) with a caffeoyl group attached to the $-3,-4$, and -5 position of quinic acid, respectively, were identified as PD-1/ PD-L1 inhibitors using SPR spectroscopic method [65]. The $K_{D}$ values of caffeoylquinic acid and its derivatives on PD-1 and PD-L1, ranged from $0.507 \times 10^{-5}$ to $1.68 \times 10^{-5} \mathrm{M}$ and from $1.71 \times 10^{-5}$ to $8.13 \times 10^{-5} \mathrm{M}$, respectively, as determined by SPR (Table 1 ). In addition, a competitive SPR assay was used to compare the binding capacity between quinic acid derivatives with one or two caffeoyl group(s) and PD-1. It was concluded that, as compared to dicaffeoylquinic acids, mono-caffeoylquinic acid derivatives had a stronger binding affinity with PD-1 and PD-L1.

\section{Heterocyclic compounds}

Several heterocyclic compounds containing nitrogen atoms have been reported to show blockage effects against PD-1/PD-L1 interactions. Using in silico virtual screening methods, Lung et al. reported that two pyrrolidine-oxadiazole derivatives including (3S,3aR,6S,6aR)-N6-[4-(3-fluorophenyl)-pyrimidin-2-yl]N3-(2-pyridylmethyl)-2,3,3a,5,6,6a-hexahydrofu (ZINC ID\#67902090) and 1-isopropyl-3-[(3S,5S)-1-methyl-5-[3(2-naphthyl)-1,2,4-oxadiazol-5-yl]pyrrolidin-3-yl]urea (ZINC ID\#12529904) were identified as PD-1/PD-L1 inhibitors among 180,000 natural compounds from the ZINC12 database [119]. The inhibitory effects of ZINC 67,902,090 and 12,529,904 were evaluated by the AlphaLISA binding and PD-L1 dimer formation assays. AlphaLISA binding assays demonstrated that ZINC 67,902,090 and $12,529,904$ have the potencies of 30 to $40 \%$ for inhibiting the PD-1/PD-L1 interaction, as compared to BMS-202 (100\%). PD-L1 dimer formation assay showed that ZINC12529904 significantly promoted the amount 
of PD-L1 dimer, whilst ZINC 67,902,090 only slightly increased the amount of PD-L1 dimer. The binding mode of these two compounds was supported by the molecular docking study but their direct binding affinities were not investigated.

\section{Perspective}

In 2018, the Nobel Prize in Physiology or Medicine was awarded to James Allison and Tasuku Honjo for their discovery of immune checkpoint therapy $[120,121]$. PD-1 functions as a T-cell brake and the activation of PD-1/ PD-L1 suppresses T cell's proliferation, survival, and activity in the tumor microenvironment [31]. Clinical studies supported that PD-1/PD-L1 blockage can effectively introduce durable antitumor immune responses with less toxicity in many types of cancers [16]. Currently, the majority of approved PD-1/PD-L1 inhibitors are mAbs $[16,109]$ while the development of small molecule inhibitors directly blocking PD-1/PD-L1 interactions is still in the stage of infancy.

Over the past decade, with a more advanced understanding of PD-1/PD-L1 interactions and the underlying mechanisms, there has been an explosion of interest in the development of bioassays that can be applied for screening small molecule inhibitors against PD-1/PD-L1 $[64,88,101,102,104]$. Biophysical and biochemical assays are powerful for screening the promising "hits" and for characterizing the binding parameters between identified "hits" and PD-1/PD-L1. Assays including ELISA, alphaLISA, bioluminescent reporter cell-based assays, and T-cell based assays are crucial to eliminate false positive "hits" as well as evaluate their biological functions. A rational workflow was established for screening PD-1/ PD-L1 inhibitors (Fig. 5a). SPR technology was performed to evaluate binding affinities between small molecule and PD-L1. The identified PD-L1 inhibitors were selected for PD-1/PD-L1 pair ELISA assay. Once the inhibitors exert blockage effects on PD-1/PD-L1 interactions, bioluminescence reporter cell-based assay can be applied for determining their biological functions. The identified PD-L1 inhibitor without blockage effects on PD-1/PD-L1 interactions is a "false" positive hit. For instance, punicalagin (PA) is an ellagitannin found in pomegranate (Punica granatum). Our screening data demonstrated that PA exhibits a stronger binding affinity with PD-L1 than BMS-1166, a positive PD-L1 inhibitor (Fig. $4 \mathrm{~b}$ ). The $\mathrm{K}_{\mathrm{D}}$ value of $5.5 \times 10^{-10} \mathrm{M}$ is determined by SPR. Notably, the PD-1/PD-L1 pair ELISA demonstrated that PA only showed minor blockage effects against PD-1/PD-L1 interactions (Fig. 5b). As discussed, biophysical methods, such as SPR, provides binding parameters of identified inhibitor with PD-1 and/or PD-L1. a

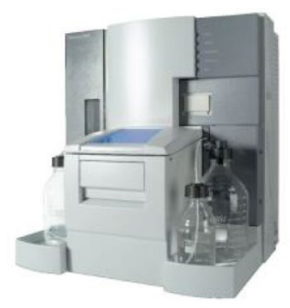

Surface plasmon resonance

Binding of PA with PD-L1

b

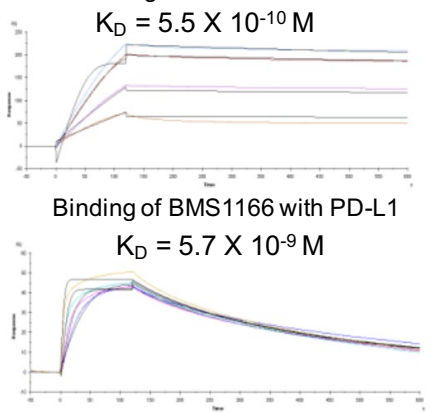

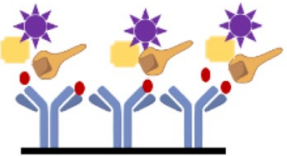

PD-1/PD-L1 pair ELISA

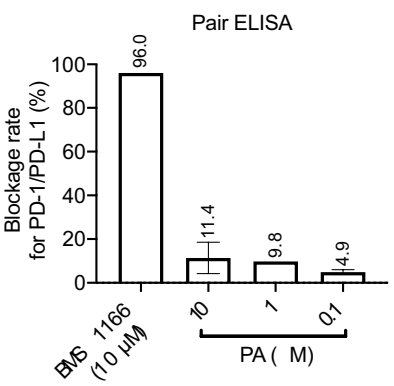

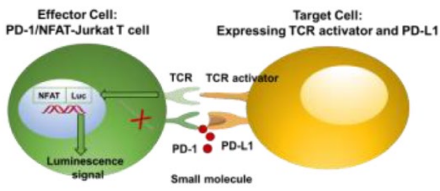

Bioluminescence reporter cell-based assay

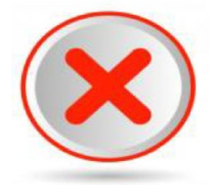

Conclusion: PA is a false positive hit.

Fig. 5 A workflow was established for screening PD-1/PD-L1 inhibitors. a SPR technology was performed to evaluate binding affinities followed by PD-1/PD-L1 pair ELISA assay. Once the inhibitors exert blockage effects on PD-1/PD-L1 interactions, bioluminescence reporter cell-based assay will be applied for determining their biological functions. $\mathbf{b}$ The binding and inhibitory effects of Punicalagin (PA) and BMS1166 against human PD-L1 protein assessed using SPR and PD-1/PD-L1 pair ELISA assays, respectively. PA or BMS1166 was allowed to flow over Fc-PD-L1 captured on a flow cell as well as on a reference cell of Series S Sensor Chip 
However, PA might not exert blockage effects towards PD-1/PD-L1 even if it has strong binding affinities with PD-L1. Future studies with in vivo models are warranted to confirm this.

As summarized, the PD-1/PD-L1 interface is challenging to target because of its large and flat hydrophobic interface. Binding parameters need to be measured for the small molecules and PD-1/PD-L1 interactions including the ones at their interactive interface and other non-interactive sites. Therefore, it is important to properly apply complementary approaches including biophysical, biochemical, and cell-based assays to achieve robust measurements. These combination strategies are critical to eliminate false positive "hits" (such as PA as demonstrated in this review), which may only have binding capacity without blockage effects on PD-1/PD-L1 interaction. Nevertheless, we believe that more versatile and advanced bioassays can be developed in the future to shed more light on the discovery of PD-1/PD-L1 inhibitors.

\begin{abstract}
Abbreviations
APCs: Antigen-presenting cells; BLI: Biolayer interferometry; CD: Circular dichroism; CLTA-4: Cytotoxic T-lymphocyte-associated protein 4; DCs: Dendritic cells; DSF: Differential scanning fluorometry; ELISA: Enzyme-linked immunosorbent assay; FPIA: Fluorescence polarization immunoassay; HTRF: Homogeneous time resolved fluorescence; irAEs: Immune-related adverse effects; IFN: Interferon; Ig: Immunoglobulin; LL: Interleukin; ITC: Isothermal titration calorimetry; ITIM: Immunoreceptor tyrosine-based inhibitory motif; ITSM: Immunoreceptor tyrosine-based switch motif; MDS: Microfluidic diffusional sizing; MST: Microscale thermophoresis; mTOR: Mechanistic targets of rapamycin; NMR: Nuclear magnetic resonance; PA: Punicalagin; PCR: Polymerase chain reaction; PD-1: Programmed cell death protein 1; PD-L1: Programmed death-ligand 1; PI3K: Phosphatidylinositol 3-kinase; SHP: Src homology 2 domain-containing protein tyrosine phosphatase; SPE: Salvia plebeia R. Br. Extract; SPR: Surface plasmon resonance; TCR: T-cell receptor; w-AIDA-NMR: Weak-antagonist induced dissociation assay-NMR; WB: Western blotting.
\end{abstract}

\section{Acknowledgements}

Not applicable.

\section{Authors' contributions}

$\mathrm{CL}, \mathrm{HM}$ conceived, designed the overall project, and wrote the manuscript. NS critically revised the manuscript. All authors read and approved the final manuscript.

\section{Funding}

Not applicable.

\section{Availability of data and materials}

Not applicable.

\section{Declarations}

Ethics approval and consent to participate Not applicable.

\section{Consent for publication}

Not applicable.

\section{Competing interests}

The authors declare no competing financial interests.
Received: 28 January 2021 Accepted: 19 April 2021

Published online: 27 April 2021

\section{References}

1. Fernandes M, Brabek J. Cancer, checkpoint inhibitors, and confusion. Lancet Oncol. 2017;18(11):e632.

2. Dunn GP, Bruce AT, Ikeda H, Old LJ, Schreiber RD. Cancer immunoediting: from immunosurveillance to tumor escape. Nat Immunol. 2002:3(11):991-8.

3. Sathyanarayanan V, Neelapu SS. Cancer immunotherapy: strategies for personalization and combinatorial approaches. Mol Oncol. 2015;9(10):2043-53.

4. Durant JR. Immunotherapy of cancer: the end of the beginning? N Engl J Med. 1987;316(15):939-41.

5. Farkona S, Diamandis EP, Blasutig IM. Cancer immunotherapy: the beginning of the end of cancer? BMC Med. 2016;14:73.

6. June $\mathrm{CH}$. Adoptive $\mathrm{T}$ cell therapy for cancer in the clinic. J Clin Invest. 2007;117(6):1466-76

7. Liu J, Yuan Y, Chen W, Putra J, Suriawinata AA, Schenk AD, Miller HE, Guleria I, Barth RJ, Huang YH, et al. Immune-checkpoint proteins VISTA and PD-1 nonredundantly regulate murine T-cell responses. Proc Natl Acad Sci USA. 2015:112(21):6682-7.

8. Ramsay AG. Immune checkpoint blockade immunotherapy to activate anti-tumour T-cell immunity. Br J Haematol. 2013;162(3):313-25.

9. Bethune MT, Joglekar AV. Personalized T cell-mediated cancer immunotherapy: progress and challenges. Curr Opin Biotechnol. 2017:48:142-52.

10. Colombo MP, Piconese S. Regulatory-T-cell inhibition versus depletion: the right choice in cancer immunotherapy. Nat Rev Cancer. 2007;7(11):880-7.

11. Kalos $\mathrm{M}$, June $\mathrm{CH}$. Adoptive T cell transfer for cancer immunotherapy in the era of synthetic biology. Immunity. 2013;39(1):49-60.

12. Paulos $C M$, June $C H$. Putting the brakes on BTLA in T cell-mediated cancer immunotherapy. J Clin Invest. 2010;120(1):76-80.

13. Wang M, Yin B, Wang HY, Wang RF. Current advances in T-cell-based cancer immunotherapy. Immunotherapy. 2014;6(12):1265-78.

14. Chen L, Han X. Anti-PD-1/PD-L1 therapy of human cancer: past, present, and future. J Clin Invest. 2015;125(9):3384-91.

15. Akinleye A, Rasool Z. Immune checkpoint inhibitors of PD-L1 as cancer therapeutics. J Hematol Oncol. 2019;12(1):92.

16. Yan Y, Zhang L, Zuo Y, Qian H, Liu C. Immune checkpoint blockade in cancer immunotherapy: mechanisms, clinical outcomes, and safety profiles of PD-1/PD-L1 inhibitors. Arch Immunol Ther Exp. 2020;68(6):1-15.

17. Alsaab HO, Sau S, Alzhrani R, Tatiparti K, Bhise K, Kashaw SK, Iyer AK. PD-1 and PD-L1 checkpoint signaling inhibition for cancer immunotherapy: mechanism, combinations, and clinical outcome. Front Pharmacol. 2017:8:561.

18. Zitvogel L, Kroemer G. Targeting PD-1/PD-L1 interactions for cancer immunotherapy. Oncoimmunology. 2012;1 (8):1223-5.

19. Topalian SL, Drake CG, Pardoll DM. Targeting the PD-1/B7-H1 (PDL1) pathway to activate anti-tumor immunity. Curr Opin Immunol. 2012:24(2):207-12

20. Saresella M, Rainone V, Al-Daghri NM, Clerici M, Trabattoni D. The PD-1/ PD-L1 pathway in human pathology. Curr Mol Med. 2012:12(3):259-67.

21. Day CL, Kaufmann DE, Kiepiela P, Brown JA, Moodley ES, Reddy S, Mackey EW, Miller JD, Leslie AJ, DePierres C, et al. PD-1 expression on HIV-specific T cells is associated with T-cell exhaustion and disease progression. Nature. 2006;443(7109):350-4.

22. Elrefaei M, Baker CA, Jones NG, Bangsberg DR, Cao H. Presence of suppressor HIV-specific CD8+ T cells is associated with increased PD-1 expression on effector CD8+ T cells. J Immunol. 2008;180(11):7757-63.

23. Wang LL, Li ZH, Hu XH, Muyayalo KP, Zhang YH, Liao AH. The roles of the PD-1/PD-L1 pathway at immunologically privileged sites. Am J Reprod Immunol. 2017;78(2):e12710.

24. Mu CY, Huang JA, Chen Y, Chen C, Zhang XG. High expression of PD-L1 in lung cancer may contribute to poor prognosis and tumor cells immune escape through suppressing tumor infiltrating dendritic cells maturation. Med Oncol. 2011;28(3):682-8. 
25. Aguilar EJ, Ricciuti B, Gainor JF, Kehl KL, Kravets S, Dahlberg S, Nishino M, Sholl LM, Adeni A, Subegdjo S, et al. Outcomes to first-line pembrolizumab in patients with non-small-cell lung cancer and very high PD-L1 expression. Ann Oncol. 2019;30(10):1653-9.

26. Ishizuka S, Sakata S, Yoshida C, Takaki A, Saeki S, Nakamura K, Fujii K. Successful treatment by pembrolizumab in a patient with end-stage renal disease with advanced non-small cell lung cancer and high PD-L1 expression. Respir Investig. 2018;56(4):361-4.

27. Fusi A, Festino L, Botti G, Masucci G, Melero I, Lorigan P, Ascierto PA. PD-L1 expression as a potential predictive biomarker. Lancet Oncol. 2015;16(13):1285-7.

28. Jiang C, Cao S, Li N, Jiang L, Sun T. PD-1 and PD-L1 correlated gene expression profiles and their association with clinical outcomes of breast cancer. Cancer Cell Int. 2019;19(1):1-9.

29. Gu X, Dong M, Liu Z, Mi Y, Yang J, Zhang Z, Liu K, Jiang L, Zhang Y, Dong S. Elevated PD-L1 expression predicts poor survival outcomes in patients with cervical cancer. Cancer Cell Int. 2019;19(1):1-9.

30. Shang J, Song Q, Yang Z, Sun X, Xue M, Chen W, Yang J, Wang S. Analysis of PD-1 related immune transcriptional profile in different cancer types. Cancer Cell Int. 2018;18(1):1-11.

31. Han Y, Liu D, Li L. PD-1/PD-L1 pathway: current researches in cancer. Am J Cancer Res. 2020;10(3):727-42.

32. Salmaninejad A, Valilou SF, Shabgah AG, Aslani S, Alimardani M, Pasdar A, Sahebkar A. PD-1/PD-L1 pathway: Basic biology and role in cancer immunotherapy. J Cell Physiol. 2019;234(10):16824-37.

33. Wu B, Sun X, Gupta HB, Yuan B, Li J, Ge F, Chiang HC, Zhang X, Zhang C, Zhang D, et al. Adipose PD-L1 modulates PD-1/PD-L1 checkpoint blockade immunotherapy efficacy in breast cancer. Oncoimmunology. 2018;7(11):e1500107.

34. Tang F, Zheng P. Tumor cells versus host immune cells: whose PD-L1 contributes to PD-1/PD-L1 blockade mediated cancer immunotherapy? Cell Biosci. 2018;8:34.

35. Ohaegbulam KC, Assal A, Lazar-Molnar E, Yao Y, Zang X. Human cancer immunotherapy with antibodies to the PD-1 and PD-L1 pathway. Trends Mol Med. 2015;21(1):24-33.

36. Xin YuJ, Hodge JP, Oliva C, Neftelinov ST, Hubbard-Lucey VM, Tang J. Trends in clinical development for PD-1/PD-L1 inhibitors. Nat Rev Drug Discov. 2020;19(3):163-4.

37. Kim ES. Avelumab: first global approval. Drugs. 2017;77(8):929-37.

38. Massard C, Gordon MS, Sharma S, Rafii S, Wainberg ZA, Luke J, Curiel TJ, Colon-Otero G, Hamid O, Sanborn RE, et al. Safety and efficacy of durvalumab (MEDI4736), an anti-programmed cell death ligand-1 immune checkpoint inhibitor, in patients with advanced urothelial bladder cancer. J Clin Oncol. 2016;34(26):3119-25.

39. Zinzani PL, Ribrag V, Moskowitz CH, Michot JM, Kuruvilla J, Balakumaran A, Zhang Y, Chlosta S, Shipp MA, Armand P. Safety and tolerability of pembrolizumab in patients with relapsed/refractory primary mediastinal large B-cell lymphoma. Blood. 2017;130(3):267-70

40. Hamanishi J, Mandai M, Ikeda T, Minami M, Kawaguchi A, Murayama T, Kanai M, Mori Y, Matsumoto S, Chikuma S, et al. Safety and antitumor activity of anti-PD-1 antibody, nivolumab, in patients with platinumresistant ovarian cancer. J Clin Oncol. 2015;33(34):4015-22.

41. Reilly RM, Sandhu J, Alvarez-Diez TM, Gallinger S, Kirsh J, Stern H. Problems of delivery of monoclonal antibodies. Pharmaceutical and pharmacokinetic solutions. Clin Pharmacokinet. 1995;28(2):126-42.

42. Zhan MM, Hu XQ, Liu XX, Ruan BF, Xu J, Liao C. From monoclonal antibodies to small molecules: the development of inhibitors targeting the PD-1/PD-L1 pathway. Drug Discov Today. 2016;21 (6):1027-36.

43. Shaabani S, Huizinga HP, Butera R, Kouchi A, Guzik K, Magiera-Mularz K, Holak TA, Dömling A. A patent review on PD-1/PD-L1 antagonists: small molecules, peptides, and macrocycles (2015-2018). Expert Opin Ther Pat. 2018;28(9):665-78.

44. Ganesan A, Ahmed M, Okoye I, Arutyunova E, Babu D, Turnbull WL, Kundu JK, Shields J, Agopsowicz KC, Xu L, et al. Comprehensive in vitro characterization of PD-L1 small molecule inhibitors. Sci Rep. 2019:9(1):12392.

45. Liu D, Wang S, Bindeman W. Clinical applications of PD-L1 bioassays for cancer immunotherapy. J Hematol Oncol. 2017;10(1):1 10.

46. Diggs LP, Hsueh EC. Utility of PD-L1 immunohistochemistry assays for predicting PD-1/PD-L1 inhibitor response. Biomark Res. 2017;5(1):12.
47. Doronin A, Gordeev A, Kozlov A, Smirnova YA, Puchkova MY, Ekimova V, Basovskiy Yl, Solovyev V. T-Cell engagers based bioassay for evaluation of PD-1/PD-L1 inhibitors activity. Biochem Mosc. 2019;84(7):711-9.

48. Patsoukis N, Wang Q, Strauss L, Boussiotis VA. Revisiting the PD-1 pathway. Sci Adv. 2020;6(38):eabd2712.

49. Bally AP, Austin JW, Boss JM. Genetic and epigenetic regulation of PD-1 expression. J Immunol. 2016;196(6):2431-7.

50. Simon S, Labarriere N. PD-1 expression on tumor-specific T cells: friend or foe for immunotherapy? Oncoimmunology. 2017;7(1):e1364828.

51. Francisco LM, Sage PT, Sharpe AH. The PD-1 pathway in tolerance and autoimmunity. Immunol Rev. 2010;236:219-42.

52. Riella LV, Paterson AM, Sharpe AH, Chandraker A. Role of the PD-1 pathway in the immune response. Am J Transplant. 2012;12(10):2575-87.

53. Cheng X, Veverka V, Radhakrishnan A, Waters LC, Muskett FW, Morgan SH, Huo J, Yu C, Evans EJ, Leslie AJ, et al. Structure and interactions of the human programmed cell death 1 receptor. J Biol Chem. 2013;288(17):11771-85.

54. Brusa D, Serra S, Coscia M, Rossi D, D'Arena G, Laurenti L, Jaksic O, Fedele G, Inghirami G, Gaidano G. The PD-1/PD-L1 axis contributes to T-cell dysfunction in chronic lymphocytic leukemia. Haematologica. 2013;98(6):953-63.

55. Latchman $Y$, Wood CR, Chernova T, Chaudhary D, Borde M, Chernova I, Iwai Y, Long AJ, Brown JA, Nunes R. PD-L2 is a second ligand for PD-1 and inhibits T cell activation. Nat Immunol. 2001:2(3):261-8.

56. Jiang X, Wang J, Deng X, Xiong F, Ge J, Xiang B, Wu X, Ma J, Zhou M, Li $X$, et al. Role of the tumor microenvironment in PD-L1/PD-1-mediated tumor immune escape. Mol Cancer. 2019;18(1):10.

57. Escors D, Gato-Canas M, Zuazo M, Arasanz H, Garcia-Granda MJ, Vera R, Kochan G. The intracellular signalosome of PD-L1 in cancer cells. Signal Transduct Target Ther. 2018;3:26.

58. Keir ME, Butte MJ, Freeman GJ, Sharpe AH. PD-1 and its ligands in tolerance and immunity. Annu Rev Immunol. 2008;26:677-704.

59. Fife BT, Pauken KE, Eagar TN, Obu T, Wu J, Tang Q, Azuma M, Krummel MF, Bluestone JA. Interactions between PD-1 and PD-L1 promote tolerance by blocking the TCR-induced stop signal. Nat Immunol. 2009;10(11):1185

60. Sheppard KA, Fitz LJ, Lee JM, Benander C, George JA, Wooters J, Qiu Y, Jussif JM, Carter LL, Wood CR, et al. PD-1 inhibits T-cell receptor induced phosphorylation of the ZAP70/CD3zeta signalosome and downstream signaling to PKCtheta. FEBS Lett. 2004;574(1-3):37-41.

61. Arasanz H, Gato-Canas M, Zuazo M, Ibanez-Vea M, Breckpot K, Kochan G, Escors D. PD1 signal transduction pathways in T cells. Oncotarget. 2017:8(31):51936-45.

62. Ai L, Xu A, Xu J. Roles of PD-1/PD-L1 pathway: signaling, cancer, and beyond. Adv Exp Med Biol. 2020;1248:33-59.

63. Barclay J, Creswell J, Leon J. Cancer immunotherapy and the PD-1/ PD-L1 checkpoint pathway. Arch Esp Urol. 2018;71(4):393-9.

64. Guzik K, Tomala M, Muszak D, Konieczny M, Hec A, Błaszkiewicz U, Pustuła M, Butera R, Dömling A, Holak TA. Development of the inhibitors that target the PD-1/PD-L1 interaction - a brief look at progress on small molecules, peptides and macrocycles. Molecules. 2019;24(11):2071.

65. Han Y, Gao Y, He T, Wang D, Guo N, Zhang X, Chen S, Wang H. PD-1/ PD-L1 inhibitor screening of caffeoylquinic acid compounds using surface plasmon resonance spectroscopy. Anal Biochem. 2018;547:52-6.

66. Lin X, Lu X, Luo G, Xiang H. Progress in PD-1/PD-L1 pathway inhibitors: from biomacromolecules to small molecules. Eur J Med Chem. 2020;186:111876.

67. Magnez R, Thiroux B, Taront S, Segaoula Z, Quesnel B, Thuru X. PD-1/ PD-L1 binding studies using microscale thermophoresis. Sci Rep. 2017;7(1):17623.

68. Lee HT, Lee $\mathrm{SH}$, Heo Y-S. Molecular interactions of antibody drugs targeting PD-1, PD-L1, and CTLA-4 in immuno-oncology. Molecules. 2019;24(6):1190.

69. Pattnaik P. Surface plasmon resonance. Appl Biochem Biotechnol. 2005:126(2):79-92.

70. Concepcion J, Witte K, Wartchow C, Choo S, Yao D, Persson H, Wei J, Li P, Heidecker B, Ma W, et al. Label-free detection of biomolecular interactions using BioLayer interferometry for kinetic characterization. Comb Chem High Throughput Screen. 2009;12(8):791-800. 
71. Ghai R, Falconer RJ, Collins BM. Applications of isothermal titration calorimetry in pure and applied research - survey of the literature from 2010. J Mol Recognit. 2012;25(1):32-52.

72. Pascolutti R, Sun X, Kao J, Maute RL, Ring AM, Bowman GR, Kruse AC. Structure and dynamics of PD-L1 and an ultra-high-affinity PD-1 Receptor Mutant. Structure. 2016;24(10):1719-28.

73. Wienken CJ, Baaske P, Rothbauer U, Braun D, Duhr S. Protein-binding assays in biological liquids using microscale thermophoresis. Nat Commun. 2010;1:100.

74. Jerabek-Willemsen M, Wienken CJ, Braun D, Baaske P, Duhr S. Molecular interaction studies using microscale thermophoresis. Assay Drug Dev Technol. 2011;9(4):342-53.

75. Gontier A, Varela PF, Nemoz C, Ropars V, Aumont-Nicaise M, Desmadril M, Charbonnier J-B. Measurements of protein-DNA complexes interactions by isothermal titration calorimetry (ITC) and microscale thermophoresis (MST). In: Multiprotein complexes. Springer; 2021. pp. 125-43.

76. Zhang X, Schwartz JC, Guo X, Bhatia S, Cao E, Lorenz M, Cammer M, Chen L, Zhang ZY, Edidin MA, et al. Structural and functional analysis of the costimulatory receptor programmed death-1. Immunity. 2004;20(3):337-47.

77. Niesen FH, Berglund $\mathrm{H}$, Vedadi M. The use of differential scanning fluorimetry to detect ligand interactions that promote protein stability. Nat Protoc. 2007;2(9):2212.

78. Matulis D, Kranz JK, Salemme FR, Todd MJ. Thermodynamic stability of carbonic anhydrase: measurements of binding affinity and stoichiometry using ThermoFluor. Biochemistry. 2005;44(13):5258-66.

79. Zak KM, Grudnik P, Guzik K, Zieba BJ, Musielak B, Dömling A, Dubin $G$, Holak TA. Structural basis for small molecule targeting of the programmed death ligand 1 (PD-L1). Oncotarget. 2016;7(21):30323.

80. Askin SP, Bond TE, Schaeffer PM. Green fluorescent protein-based assays for high-throughput functional characterization and ligand-binding studies of biotin protein ligase. Anal Methods. 2016;8(2):418-24.

81. Lea WA, Simeonov A. Fluorescence polarization assays in small molecule screening. Expert Opin Drug Discov. 2011;6(1):17-32.

82. Zhou K, Lu J, Yin X, Xu H, Li L, Ma B. Structure-based derivation and intramolecular cyclization of peptide inhibitors from PD-1/PD-L1 complex interface as immune checkpoint blockade for breast cancer immunotherapy. Biophys Chem. 2019;253:106213.

83. Moerke NJ. Fluorescence polarization (FP) assays for monitoring peptide-protein or nucleic acid-protein binding. Curr Protoc Chem Biol. 2009;1(1):1-15.

84. Jeong W-J, Bu J, Han Y, Drelich AJ, Nair A, Král P, Hong S. Nanoparticle conjugation stabilizes and multimerizes $\beta$-hairpin peptides to effectively target PD-1/PD-L1 $\beta$-sheet-rich interfaces. J Am Chem Soc. 2020;142(4):1832-7

85. Musielak B, Janczyk W, Rodriguez I, Plewka J, Sala D, Magiera-Mularz K, Holak T. Competition NMR for detection of hit/lead inhibitors of protein-protein interactions. Molecules. 2020;25(13):3017.

86. Babaoglu K, Shoichet BK. Deconstructing fragment-based inhibitor discovery. Nat Chem Biol. 2006;2(12):720-3.

87. Fielding L. NMR methods for the determination of protein-ligand dissociation constants. Curr Top Med Chem. 2003;3(1):39-53.

88. Perry E, Mills JJ, Zhao B, Wang F, Sun Q, Christov PP, Tarr JC, RietzTA, Olejniczak ET, Lee T, et al. Fragment-based screening of programmed death ligand 1 (PD-L1). Bioorg Med Chem Lett. 2019;29(6):786-90.

89. Zak KM, Grudnik P, Guzik K, Zieba BJ, Musielak B, Domling A, Dubin $G$, Holak TA. Structural basis for small molecule targeting of the programmed death ligand 1 (PD-L1). Oncotarget. 2016;7(21):30323-35.

90. Skinner AL, Laurence JS. High-field solution NMR spectroscopy as a tool for assessing protein interactions with small molecule ligands. J Pharm Sci. 2008;97(11):4670-95.

91. Lequin RM. Enzyme immunoassay (EIA)/enzyme-linked immunosorbent assay (ELISA). Clin Chem. 2005;51(12):2415-8.

92. Cauchon E, Liu S, Percival MD, Rowland SE, Xu D, Binkert C, Strickner P, Falgueyret J-P. Development of a homogeneous immunoassay for the detection of angiotensin I in plasma using AlphaLISA acceptor beads technology. Anal Biochem. 2009;388(1):134-9.

93. Cheng Z-J, Karassina N, Grailer J, Hartnett J, Fan F, Cong M. novel PD-1 blockade bioassay to assess therapeutic antibodies in PD-1 and PD-L1 immunotherapy programs. Cancer Res. 2015;75(Suppl):abstr 5440.
94. Pahl HL. Activators and target genes of Rel/NF-kappaB transcription factors. Oncogene. 1999;18(49):6853-66.

95. Vaeth M, Feske S. NFAT control of immune function: new frontiers for an abiding trooper. F1000Res. 2018;7:260.

96. Zhou X, Mehta S, Zhang J. Genetically encodable fluorescent and bioluminescent biosensors light up signaling networks. Trends Biochem Sci. 2020:45:889-905.

97. Davari K, Holland T, Prassmayer L, Longinotti G, Ganley K, Pechilis L, Diaconu I, Nambiar P, Magee M, Schendel D. 161 Development of a CD8 co-receptor independent $T$ cell receptor specific for tumor-associated antigen MAGE-A4 for next generation T cell-based immunotherapy. In: BMJ specialist journals; 2020.

98. Mizuno R, Sugiura D, Shimizu K, Maruhashi T, Watada M, Okazaki IM, Okazaki T. PD-1 primarily targets TCR signal in the inhibition of functional T cell activation. Front Immunol. 2019;10:630.

99. Hsieh Y-T, Aggarwal P, Cirelli D, Gu L, Surowy T, Mozier NM. Characterization of FcyRIIIA effector cells used in in vitro ADCC bioassay: comparison of primary NK cells with engineered NK-92 and Jurkat T cells. J Immunol Methods. 2017:441:56-66.

100. Abraham RT, Weiss A. Jurkat T cells and development of the T-cell receptor signalling paradigm. Nat Rev Immunol. 2004;4(4):301-8.

101. Versteven M, Van den Bergh JMJ, Broos K, Fujiki F, Campillo-Davo D, De Reu H, Morimoto S, Lecocq Q, Keyaerts M, Berneman Z, et al. A versatile T cell-based assay to assess therapeutic antigen-specific PD-1-targeted approaches. Oncotarget. 2018;9(45):27797-808.

102. Zhai W, Zhou X, Du J, Gao Y. In vitro assay for the development of small molecule inhibitors targeting PD-1/PD-L1. Methods Enzymol. 2019;629:361-81.

103. Zhang R, Zhu Z, Lv H, Li F, Sun S, Li J, Lee CS. Immune checkpoint blockade mediated by a small-molecule nanoinhibitor targeting the PD-1/PD-L1 pathway synergizes with photodynamic therapy to elicit antitumor immunity and antimetastatic effects on breast cancer. Small. 2019;15(49):1903881.

104. Konieczny M, Musielak B, Kocik J, Skalniak L, Sala D, Czub M, MagieraMularz K, Rodriguez I, Myrcha M, Stec M. Di-bromo-based small-molecule inhibitors of the PD-1/PD-L1 immune checkpoint. J Med Chem. 2020;63(19):11271-85.

105. Xia A, Zhang Y, Xu J, Yin T, Lu XJ. T cell dysfunction in cancer immunity and immunotherapy. Front Immunol. 2019;10:1719.

106. Vareki SM, Garrigós C, Duran I. Biomarkers of response to PD-1/PD-L1 inhibition. Crit Rev Oncol Hematol. 2017;116:116-24.

107. Yadav J, Dikshit N, Ismaeel S, Qadri A. Innate activation of IFN- $\gamma$-iNOS axis during infection with salmonella represses the ability of T cells to produce IL-2. Front Immunol. 2020;11:514.

108. van Asten SD, de Groot R, van Loenen MM, Castenmiller SM, de Jong J, Monkhorst K, Haanen JB, Amsen D, Bex A, Spaapen RM. T cells expanded from renal cell carcinoma display tumor-specific CD137 expression but lack significant IFN- $\gamma$, TNF-a or IL-2 production. Oncolmmunology. 2021;10(1):1860482.

109. Zahavi D, Weiner L. Monoclonal antibodies in cancer therapy. Antibodies. 2020;9(3):34.

110. Fessas P, Possamai LA, Clark J, Daniels E, Gudd C, Mullish BH, Alexander JL, Pinato DJ. Immunotoxicity from checkpoint inhibitor therapy: clinical features and underlying mechanisms. Immunology. 2020;159(2):167-77.

111. Jiao P, Geng Q, Jin P, Su G, Teng H, Dong J, Yan B. Small molecules as PD-1/PD-L1 pathway modulators for cancer immunotherapy. Curr Pharm Des. 2018;24(41):4911-20.

112. Sun H, Chen D, Zhan S, Wu W, Xu H, Luo C, Su H, Feng Y, Shao W, Wan A, et al. Design and discovery of natural cyclopeptide skeleton based programmed death ligand 1 inhibitor as immune modulator for cancer therapy. J Med Chem. 2020;63(19):11286-301.

113. Patil SP, Yoon SC, Aradhya AG, Hofer J, Fink MA, Enley ES, Fisher JE, Herb MC, Klingos A, Proulx JT, et al. Macrocyclic Compounds from ansamycin antibiotic class as inhibitors of PD1-PDL1 protein-protein interaction. Chem Pharm Bull (Tokyo). 2018;66(8):773-8.

114. Kim JH, Kim YS, Choi JG, Li W, Lee EJ, Park JW, Song J, Chung HS. Kaempferol and its glycoside, kaempferol 7-O-rhamnoside, inhibit PD-1/PD-L1 interaction in vitro. Int J Mol Sci. 2020;21(9):3239. 
115. Choi JG, Kim YS, Kim JH, Kim TI, Li W, Oh TW, Jeon CH, Kim SJ, Chung HS. Anticancer effect of Salvia plebeia and its active compound by improving T-cell activity via blockade of PD-1/PD-L1 interaction in humanized PD-1 mouse model. Front Immunol. 2020;11:598556.

116. Li W, Kim TI, Kim JH, Chung HS. Immune checkpoint PD-1/PD-L1 CTLA-4/CD80 are blocked by Rhus verniciflua stokes and its active compounds. Molecules. 2019;24(22):4062.

117. Bao F, Bai HY, Wu ZR, Yang ZG. Phenolic compounds from cultivated Glycyrrhiza uralensis and their PD-1/PD-L1 inhibitory activities. Nat Prod Res. 2019;35:562-9.

118. Kim JH, Kim YS, Kim TI, Li W, Mun JG, Jeon HD, Kee JY, Choi JG, Chung HS. Unripe black raspberry (Rubus coreanus Miquel) extract and its constitute, ellagic acid induces $T$ cell activation and antitumor immunity by blocking PD-1/PD-L1 interaction. Foods. 2020;9(11):1590.

119. Lung J, Hung MS, Lin YC, Hung CH, Chen CC, Lee KD, Tsai YH. Virtual screening and in vitro evaluation of PD-1 dimer stabilizers for uncoupling PD-1/PD-L1 interaction from natural products. Molecules. 2020;25(22):5293
120. Zang X. 2018 Nobel Prize in medicine awarded to cancer immunotherapy: immune checkpoint blockade—a personal account. Genes Dis. 2018;5(4):302

121. Soren K, Kabiraj A, Goswami P, Banerjee A, Bandopadhyay R. A breakthrough on cancer therapy by inhibition of negative immune regulation: nobel prize in physiology or medicine 2018. Berlin: Springer; 2020.

\section{Publisher's Note}

Springer Nature remains neutral with regard to jurisdictional claims in published maps and institutional affiliations.
Ready to submit your research? Choose BMC and benefit from:

- fast, convenient online submission

- thorough peer review by experienced researchers in your field

- rapid publication on acceptance

- support for research data, including large and complex data types

- gold Open Access which fosters wider collaboration and increased citations

- maximum visibility for your research: over 100M website views per year

At BMC, research is always in progress.

Learn more biomedcentral.com/submissions 